\title{
JURISPRUDÊNCIA ARCO-ÍRIS: COMENTÁRIOS À DECISÃO DO SUPREMO TRIBUNAL FEDERAL ACERCA DAS UNIÕES HOMOAFETIVAS
}

\section{George Marmelstein}

Doutorando em direito pela Universidade de Coimbra. Professor de Direito Constitucional e Filosofia do Direito na FA7. Juiz Federal georgemlima@yahoo.com.br

Sumário: 1. Um Debate Necessário e Urgente. 2. Em Busca da "Vontade da Constituição". 3. O Que Está em Jogo? 4. Interpretando a Constituição. 5. Qual Era a Autêntica Intenção dos Constituintes? 6. A Interpretação do Supremo Tribunal Federal é Tão Absurda Assim?. 7. Crítica aos Críticos. 8. O Texto e o Contexto. Conclusão. Referências.

Resumo: Podem os interesses comerciais superar os interesses de saúde da população de um determinado país? Esta é a indagação feita na análise deste trabalho a partir da ótica de um juiz ao ter que decidir um determinado caso concreto de produto alimentício importado e que foi declarado impróprio para o consumo pela Agência Nacional de Vigilância Sanitária.

Palavras-chave: Interpretação constitucional. Jurisdição constitucional. Ativismo Judicial. Direitos dos homossexuais.

\section{Um Debate Necessário e Urgente}

Nos dias 4 e 5 de maio de 2011, o Supremo Tribunal Federal julgou um dos casos mais emblemáticos de sua história. Por unanimidade (10 a 0), ficou decidido que as uniões estáveis homoafetivas, ou seja, formadas por pessoas do mesmo sexo, merecem a mesma proteção jurídica dada às uniões estáveis entre homem e mulher ${ }^{1}$.

1 STF, ADPF 132/RJ, rel. Min. Ayres Brito, j. 4 e 5/5/2011. O ministro José Antônio Dias Toffolli não votou em razão de haver atuado no caso na qualidade de Advogado-Geral da União, onde havia apresentado manifestação favorável ao reconhecimento da união estável entre pessoas do mesmo sexo. Sendo assim, pode-se dizer que todos os atuais ministros tiveram o mesmo entendimento acerca do caso. 
Aplausos de um lado, perplexidade de outro, o certo é que a referida decisão abre margem para uma rica discussão em torno de vários pontos importantes para o pensamento jurídico contemporâneo, como os limites da jurisdição no Brasil, o papel do Supremo Tribunal Federal e os contornos da interpretação constitucional. É provável que esse leading case faça surgir na comunidade acadêmica brasileira um novo estilo de debate, que é o debate crítico a posteriori dos resultados produzidos pela jurisdição constitucional.

Quando lemos obras de Direito Constitucional norte-americano, encontramos, com frequência, discussões sobre casos já decididos pela Suprema Corte daquele país, analisando retrospectivamente os méritos ou deméritos da solução adotada. Referidos debates têm o propósito de influenciar casos futuros onde os mesmos princípios possam ser aplicados ou até mesmo gerar uma reviravolta jurisprudencial, o que é relativamente frequente em razão da forte divergência interna, em que muitos casos são decididos por uma maioria apertada (os julgamentos " $5 \times 4$ " são bastante comuns). Lá, portanto, os debates acadêmicos não se limitam a informar e tentar compreender o que foi decidido, mas sobretudo influenciar, pelo seu poder crítico e reflexivo, os rumos da jurisdição constitucional.

Aqui no Brasil, pelo contrário, sempre houve uma certa acomodação acadêmica em relação às decisões do Supremo Tribunal Federal, por mais polêmicas que sejam. A doutrina, de um modo geral, parece se interessar mais pelos temas ainda não decididos, talvez com a crença de que é mais fácil influir em um futuro julgamento do que mudar um caso julgado. Raramente se observam discussões acerca de temas já consolidados. Não houve, por exemplo, nenhum debate sistemático após a decisão do STF no Caso Ellwanger ${ }^{2}$, onde foi decidido que a liberdade de expressão não protege discursos que fazem apologia ao nazismo. Também não houve nenhum debate acadêmico mais profundo após o Supremo Tribunal Federal haver decidido pela constitucionalidade da Lei de Biossegurança, que autorizou a pesquisa científica com células-tronco embrionárias ${ }^{3}$. Os debates ocorreram antes do julgamento e, com a decisão judicial, o assunto esfriou, como se não houvesse mais o que fazer diante da autoridade da coisa julgada, exceto compreender o que foi decidido. É como se a voz do Supremo, a quem competiria pronunciar a "última palavra", calasse todas as demais vozes.

A decisão sobre as uniões homoafetivas, imediatamente, provocou um novo estilo de debate acadêmico, pois a comunidade jurídica parece ter percebido quão poderosa pode ser a jurisdição constitucional e quão importante é o papel da academia enquanto espaço de crítica sobre essa atividade. Agora, pelo que tenho notado, os juristas debruçam-se sobre a decisão do Supremo Tribunal Federal não apenas para compreendê-la, mas também para avaliar o seu acerto e

2 STF, HC 82424, rel. Min. Moreira Alves, relator para acórdão Min. Maurício Corrêa, j. 17/09/2003.
3 STF, ADI 3510, rel. Min. Ayres Brito, j. 29/05/2008. 
especialmente para questionar os próprios limites da jurisdição constitucional. Enquanto diversos setores da sociedade elogiavam ou lamentavam, conforme o viés ideológico, a decisão pelo seu mérito, vários artigos críticos, escritos por juristas respeitáveis, foram publicados nos dias seguintes à decisão, denunciando que o STF teria extrapolado a sua missão constitucional e violado os "limites semânticos da Constituição" (STRECK, 2011), "reescrevendo o texto da Constituição sem legitimidade para tanto" (DOUGLAS, 2011) e "criando um direito até então inexistente" (ARRUDA, 2011). Mesmo alguns autores simpáticos à causa dos homossexuais questionaram o modus operandi da decisão, pois, segundo eles, seria necessária uma revisão constitucional para reconhecer a validade jurídica das uniões homoafetivas ou, pelo menos, uma alteração legislativa, de modo que, de uma forma ou de outra, caberia ao parlamento e não ao judiciário decidir a matéria. Nesse sentido, qualquer equiparação judicial das relações homoafetivas às uniões estáveis entre homem e mulher fragilizaria o princípio democrático que exige que tais decisões sejam deliberadas na instância popular, de modo que o reconhecimento das uniões homoafetivas na esfera judicial provocaria "uma instabilidade institucional pela fissura provocada no texto da Constituição através de um protagonismo da Corte Constitucional", gerando "um tipo de mal-estar institucional gravíssimo" (STRECK, OLIVEIRA \& BARRETO, 2011). Outros, notoriamente antipáticos à causa dos homossexuais, pegaram carona nas críticas e iniciaram uma verdadeira cruzada contra a jurisdição constitucional, alegando que os ministros do Supremo Tribunal Federal, "à luz da denominada 'interpretação conforme', estão conformando a Constituição Federal à sua imagem e semelhança, e não àquela que o povo desenhou por meio de seus representantes" (MARTINS, 2011). Referidos discursos seguem uma linha bastante crítica ao protagonismo judicial exercido pelo Supremo Tribunal Federal na última década, dentro de um estilo argumentativo já existente na literatura anglo-saxã há pelo menos dois séculos, mas que sempre é atual e se renova (TUSHNET, 1999; WALDRON, 2006; BICKEL, 1962).

No presente artigo, entrarei neste debate por entender ser extremamente salutar e urgente discutir os limites da jurisdição constitucional no Brasil, pois também compartilho algumas preocupações em torno do excesso de judicialização, especialmente por conta de algumas falhas presentes no modelo atual de deliberação judicial brasileiro que não convém aqui mencionar ${ }^{4}$.

De qualquer modo, é possível perceber uma clara evolução nos debates constitucionais brasileiros nas últimas duas décadas, em que podem ser distinguidas, pelo menos, duas fases bem nítidas: a das possibilidades e a dos limites.

\footnotetext{
4 Estou desenvolvendo um artigo sobre os riscos da jurisdição constitucional onde devo aprofundar minha visão sobre as falhas do modelo de deliberação judicial adotado no Brasil.
} 
A primeira fase (das possibilidades) ocorreu durante os anos 1990. Naquela época, vivíamos um momento de transição política, tentando sair de um regime ditatorial para construir um modelo de democracia alicerçada na Constituição de 1988. A maioria dos juristas que se dedicaram ao estudo do Direito Constitucional naquele período estava essencialmente preocupada em defender a supremacia da Constituição, a efetividade das normas constitucionais e o papel do Poder Judiciário como órgão de proteção dos direitos. A produção acadêmica daquele período enaltecia a jurisdição constitucional e defendia, com otimismo, a atuação estratégica do Poder Judiciário para fazer valer a Constituição de 1988. Estávamos no campo das possibilidades. Pode o juiz deixar de aplicar uma lei inconstitucional? Pode o juiz julgar um caso invocando apenas normas constitucionais, inclusive princípios abstratos, como a dignidade humana, a igualdade ou a liberdade? Pode o juiz participar da concretização dos direitos fundamentais sociais, como a saúde, a moradia e a educação, obrigando o poder público a fornecer serviços aos indivíduos mesmo sem base legal? Essas eram as perguntas dominantes.

Uma análise da prática judiciária contemporânea, sobretudo da jurisprudência atual do Supremo Tribunal Federal, comprova que o discurso pró-jurisdição constitucional parece ter vencido e conquistado o status de pensamento dominante. O Judiciário, claramente, assumiu para si o papel de guardião da Constituição e reconfigurou completamente a feição do velho princípio da separação de poderes, participando, bem ou mal, do processo de realização dos objetivos constitucionais. Hoje, está pacificado na jurisprudência do STF o entendimento de que é possível extrair da Constituição comandos diretos ao poder público, independentemente de $l \mathrm{i}^{5}$; que o judiciário pode efetivar direitos econômicos, sociais e culturais ${ }^{6}$; que, na falta de lei regulamentadora da Constituição, o Judiciário pode regulamentar a matéria enquanto perdurar a omissão do legislador ${ }^{7}$; e assim por diante.

O detalhe é que a Constituição brasileira incorporou um catálogo amplo e variado de direitos fundamentais, redigido de forma propositadamente aberta e vaga. Com isso, o leque de matérias passíveis de serem submetidas à jurisdição constitucional aumentou substancialmente, sobretudo porque os juristas começaram a aceitar, com grande ênfase, a ideia de força normativa da Constituição e a consequente possibilidade de aplicação direta e imediata dos direitos fundamentais (CANOTILHO, 1997, p. 1208), gerando aquilo que tem sido designado como constitucionalização dos direitos (SILVA, 2005) ou ascensão do constitucionalismo (ACKERMAN, 1996; SOUZANETO \& SARMENTO, 2007).

5 STF, ADC 12, Relator(a): Min. CARLOS BRITTO, j 20/08/2008; STF, RE 579951, Relator(a): Min. RICARDO LEWANDOWSKI, Tribunal Pleno, julgado em 20/08/2008 (Nepotismo).

6 STF, RE 410715 AgR, Relator(a): Min. CELSO DE MELLO, j 22/11/2005 (Obrigação estatal de atendimento em creche e pre-escola).

7 STF, MI 708, Relator(a): Min. GILMAR MENDES, j 25/10/2007 (Omissão legislativa na regulamentação da greve do funcionalismo público); STF, ADI 3999, Relator(a): Min. JOAQUIM BARBOSA, j.12/11/2008 (Fidelidade partidária). 
A consequência disso é um excesso de judicialização dos conflitos sociais e um aumento substancial dos poderes normativos dos juízes, especialmente dos que compõem os órgãos de cúpula. No Brasil, em particular, o ativismo judicial do Supremo Tribunal Federal, sobretudo a partir do ano 2000, tem sido detectado não só por estudiosos do Direito, mas por todos aqueles que possuem um mínimo de senso político. A conhecida mensagem de Alexis de Tocqueville, ao comentar, já no século XIX, que praticamente não existem questões políticas e sociais que não se transformem, cedo ou tarde, em uma questão judicial nos Estados Unidos, também pode ser estendida para o Brasil de hoje. O número de litígios submetidos ao julgamento de órgãos judiciais aumentou consideravelmente, de modo que não é exagero falar que são poucas as disputas sociais que não se transformam em processo judicial.

Estão desaguando na justiça brasileira pedidos de pessoas que querem pôr fim à própria vida, invocando a existência de um direito de morrer dignamente, ou seja, um direito de praticar a eutanásia ou o suicídio assistido. Também é possível observar pedidos de autorização para interrupção de gravidez em caso de doença do feto, sendo mais comum o caso da anencefalia, que está na pauta de julgamento do Supremo Tribunal Federal. Há, ainda, várias ações propostas por indivíduos pertencentes a minorias, como os homossexuais, negros, minorias religiosas e grupos em desvantagem socioeconômica, que, por não terem "capital político", buscam no Judiciário um refúgio para a proteção institucional de seus interesses. Começam a surgir ações judiciais para que sejam reconhecidos os direitos morais dos primatas e dos grandes mamíferos, tentando redimensionar o sentido de pessoa merecedora de respeito e dignidade. Como se vê, tais questões envolvem aspectos extremamente complexos e estão sendo objeto de disputas judiciais e decididas, em última análise, por membros do Judiciário.

Embora esse fenômeno seja relativamente recente no Brasil, é bem mais antigo no resto do mundo, especialmente nos Estados Unidos, mas não só. $\mathrm{Na}$ verdade, mais de oitenta países no mundo aceitam e adotam o que se convencionou chamar de jurisdição constitucional dos direitos fundamentais, que é um modelo político de deliberação em que as questões constitucionais mais relevantes, sobretudo aquelas ligadas aos direitos fundamentais, são submetidas a um órgão jurisdicional ${ }^{8}$.

\footnotetext{
O jurista canadense Ran Hisrchl apelidou esse fenômeno, num tom pejorativo, de juristocracia: "over the past few years the world has witnessed an astonishingly rapid transition to what may be called juristocracy. Around the globe, in more than eighty countries and in several supranational entities, constitutional reforms has transferred an unprecedented amount of power from representative institutions to judiciaries. (...) National high courts and supranational tribunals have become increasingly important, even crucial, political decision-making bodies" (HISRCHL, 2004, p. 1). Kim Scheppelle, por sua vez, acusa o surgimento de uma Courtocracy (SCHEPPELLE, 2000). Aqui no Brasil, Oscar Vilhena Vieira introduziu o termo "Supremocracia" para desginar o fenômeno (VIEIRA, 2008).
} 
A transferência de debates morais e políticos para a esfera judicial, seja no âmbito nacional, por meio da jurisdição constitucional, seja no âmbito internacional, por meio dos tribunais internacionais de direitos humanos, parece ser uma febre mundial e, particularmente no Brasil, anda bem quente nos últimos anos.

Em razão disso, parece-me que o discurso atual, a respeito da interpretação constitucional e do papel do poder judiciário, não está mais no campo das possibilidades. Hoje, quase todos concordam que, pelo menos em algumas situações, os juízes devem se preocupar com a efetividade das normas constitucionais, sobretudo dos direitos fundamentais, e podem deixar de aplicar uma lei inconstitucional em nome da força normativa da Constituição. Até mesmo os críticos mais ácidos da jurisdição constitucional reconhecem que há casos em que a interferência judicial é salutar, embora existam muitas divergências sobre quais são esses $\operatorname{casos}^{9}$.

O importante agora é centrar o discurso nos limites da atuação judicial. Até que ponto os juízes podem agir para fazer valer a constituição? Em que situações é legítima a interferência judicial? Estão os juízes preparados para dar respostas satisfatórias aos grandes problemas morais da sociedade? Por que essas questões estão sendo decididas por juízes não eleitos ao invés de estarem sendo discutidas e deliberadas no âmbito parlamentar, que sempre foi a arena desses debates? Como conciliar tal modelo com a democracia? Quais são as vantagens e desvantagens desse modelo de deliberação judicial? Quais são os riscos que a judicialização dessas questões pode acarretar e como minimizar esses riscos? Essas são as perguntas do momento.

E quando discutimos sobre limites da jurisdição não podemos ser ingênuos. Estamos falando de poder. Poder este que tem um conhecido efeito narcótico: quanto mais se tem, mais se quer. O abuso, com boas ou más intenções, é inevitável. Portanto, quando falamos de limites à jurisdição constitucional, temos que ser realistas e deixar de lado aquela visão romântica em torno das supostas virtudes intelectuais e morais dos julgadores para reconhecer que os juízes podem errar. E às vezes, podem errar feio, como bem demonstram

\footnotetext{
9 Assim, por exemplo, John Ely, mesmo identificando os problemas políticos do "judicial review", defendeu que a jurisdição constitucional seria legítima para promover o funcionamento adequado da democracia, assegurando a abertura dos canais de participação e de mudanças políticas ("clearing the channels of political change"), bem como impedindo a tomada de decisões contrárias a direitos de minorias que não lograssem participação adequada no processo político-democrático ("facilitating the representation of minories") (ELY, 2002). Do mesmo modo, Jürgen Habermas, defendendo uma jurisdição constitucional meramente procedimental, entende que o papel dos juízes constitucionais é garantir que os procedimentos democráticos sejam respeitados de modo a permitir que o próprio povo possa decidir sobre seu destino com autonomia, não cabendo, portanto, ao Judiciário assumir a função de legislador político (HABERMAS, 1997). Para uma visão de um brasileiro sobre o debate: MENDES, 2008.
} 
os exemplos de Dred Scott ${ }^{10}$ e Plessy v. Ferguson ${ }^{11}$, nos Estados Unidos, duas decisões que ilustram de forma exemplar os riscos da jurisdição constitucional, na medida em que negaram aos negros a condição de cidadãos merecedores de direitos básicos e marcaram uma época de discriminação institucionalizada que até hoje afeta a sociedade norte-americana.

É dentro dessa preocupação em torno dos limites da jurisdição que a doutrina constitucional contemporânea tem caminhado e também pretendo seguir por essa linha. Porém, devo desde já fazer uma ressalva importante para não ser mal compreendido. Mesmo compartilhando algumas preocupações dos críticos em relação à jurisdição constitucional tal como praticada no Brasil, sairei em defesa da decisão do STF no caso da homoafetividade, por entender que, especificamente neste caso, a jurisdição constitucional fez o seu melhor: protegeu um grupo historicamente menosprezado pela sociedade que, dificilmente, conseguiria ter

${ }^{10}$ Dred Scott v. Sandford, 60 U.S. (19 How.) 393 (1857). On-line: http://laws.findlaw.com/us/60/393.html. Ressalte-se que, no referido julgamento, iniciou-se a construção do chamado substantive due process. A cláusula do devido processo foi adotada para declarar a inconstitucionalidade do "Missouri Compromise", que proibia a escravidão em novos territórios existentes acima de determinada latitude nos Estados Unidos. O fundamento citado pelo juiz Taney, relator do caso, foi este: "um ato do Congresso que priva um cidadão dos Estados Unidos de sua liberdade ou propriedade meramente porque ele foi ou levou sua propriedade para um território específico dos Estados Unidos, e que não cometeu nenhuma ofensa contra as leis, dificilmente poderia ser dignificado como devido processo legal". No Brasil, é costume no meio jurídico elogiar a construção "substantiva" da cláusula do devido processo como se fosse o melhor instrumento para barrar as leis materialmente irrazoáveis. Talvez seja mesmo. Mas o que poucos sabem é que essa ideia não foi criada para anular uma lei substancialmente injusta. O propósito, pelo menos no caso Dred Scott, foi o de invalidar uma lei que era totalmente a favor dos direitos fundamentais, já que proibia a escravidão em determinados territórios.

${ }^{11}$ Plessy v. Ferguson, 163 U.S. 537 (1896). On-line: http://laws.findlaw.com/us/163/537.html. No referido caso, a Suprema Corte, com apenas um voto contrário, decidiu que a reserva de acomodações "separadas, mas iguais" para negros nos transportes ferroviários seria compatível com o princípio da igualdade, já que essa teria sido a intenção dos legisladores que aprovaram a cláusula da igualdade. Os fatos que deram origem ao processo judicial, pelo menos em sua versão mais conhecida, foram estes: um senhor chamado Homer Plessy, que tinha ascendência negra, comprou uma passagem de trem na primeira classe. Quando já estava no vagão, a polícia foi chamada, pois aquela área era privativa de pessoas brancas. Plessy se negou a sair do vagão e, por isso, foi preso e condenado por violar a lei estadual que autorizava a reserva de áreas exclusivas para brancos em transportes coletivos. No caso em questão, a Suprema Corte confirmou a punição sofrida pelo senhor Plessy (informações obtidas a partir de: IRONS, 1999). O único juiz da Suprema Corte que não concordou com o julgamento foi Jonh Harlan, que, além de ter afirmado que a Constituição é cega quanto a cor dos indivíduos ("color-blind"), foi profético ao assinalar no seu voto: "Na minha opinião, o julgamento que hoje se concluiu se mostrará, com o tempo, tão pernicioso quanto a decisão tomada neste tribunal no Caso Dred Scott. A presente decisão não apenas estimulará a discriminação e a agressão contra os negros como também permitirá que, por meio de normas estatais, sejam neutralizadas as benéficas conquistas aprovadas com as recentes mudanças constitucionais". Desde então, como bem profetizou o juiz Harlan, várias medidas segregacionistas foram adotadas por diversos Estados e reconhecidas como válidas pela Suprema Corte. Pode-se mencionar, por exemplo, o caso Berea College v. Kentucky (1908), onde foi aceita uma lei do Estado de Kentucky que proibia que as escolas particulares admitissem brancos e pretos na mesma instituição, bem como o caso Gong Lum v. Rice (1927), que equiparou as crianças de origem chinesas aos negros para fins de matrícula escolar. No caso Corrigan v. Buccley (1926), a Suprema Corte disse que não violava o devido processo nem o princípio da igual proteção, uma cláusula contida em contrato de compra e venda de imóvel que proibia o aluguel ou a transferência do imóvel para qualquer pessoa negra. 
os seus direitos reconhecidos dentro do debate parlamentar. Não considero que houve qualquer excesso interpretativo por parte do STF e tentarei comprovar que a interpretação adotada é perfeitamente compatível com o texto constitucional.

Minha abordagem será compreensiva em relação aos posicionamentos críticos. Embora existam muitos grupos preconceituosos que reclamam da decisão do Supremo Tribunal Federal por não concordarem com o seu mérito, é inegável que há também muitos argumentos razoáveis e não preconceituosos que podem ser invocados contra a decisão e, portanto, não se pode dizer que quem é contra a decisão do STF é necessariamente homofóbico e conservador. Esse tipo de atitude - de desqualificar de plano qualquer argumento contrário à decisão do STF - é dogmática e não condiz com um bom debate acadêmico.

O tema, naturalmente, é delicado pelas paixões que suscita de ambos os lados. Há um forte preconceito contra os homossexuais, mas também há um forte preconceito contra quem não aceita a homossexualidade. Isso faz com que, muitas vezes, o discurso caia numa manipulação retórica, onde os preconceitos são encobertos com frases grandiloquentes e vários subterfúgios linguísticos são usados para impressionar e conquistar a adesão da plateia. Tentarei evitar esse tipo de estratégia, até porque, como heterossexual que sou, defenderei um posicionamento que, em princípio, não me favorece, o que me dá, penso eu, uma presunção de imparcialidade.

Para começar a discussão, é necessário investigar a origem do problema: os debates constituintes e a consequente aprovação do artigo $226, \S 3^{\circ}$, da $\mathrm{CF} / 88$, que estabelece que "para efeito da proteção do Estado, é reconhecida a união estável entre o homem e a mulher como entidade familiar, devendo a lei facilitar sua conversão em casamento".

\section{EM Busca da "Vontade da Constituição"}

A Constituição Federal de 1988 surgiu de um debate intenso na sociedade brasileira. Mesmo que se questionem alguns problemas de composição e representatividade, pela falta de amadurecimento democrático naquele período, decorrente do fato de o país ter passado por trinta anos de supressão de liberdades, não se pode negar que vários setores da sociedade tiveram voz na assembleia constituinte e muitos assuntos polêmicos foram debatidos abertamente.

Os grupos de defesa dos direitos dos homossexuais também estiveram presentes nos debates parlamentares, embora, até onde sei, não houvesse deputados constituintes confessadamente homossexuais. Os partidos de esquerda assumiram, na prática, a bandeira de luta dos gays durante os debates constituintes. Os representantes das associações de defesa dos homossexuais foram convidados para exporem seus pontos de vista e apresentarem suas reivindicações perante os parlamentares que decidiriam o futuro do país. 
Consultando os anais dos debates constituintes, é possível verificar que a principal reivindicação dos grupos de defesa dos interesses dos homossexuais era a inclusão, no texto constitucional, de forma expressa, da proibição de discriminação por motivo de orientação sexual. Essa pretensão foi incluída em um dos anteprojetos, mas gerou uma forte resistência de deputados mais conservadores.

Analisando os discursos parlamentares contra a inclusão, no texto constitucional, da proibição de discriminação por orientação sexual, percebe-se que vários deputados constituintes eram claramente preconceituosos em relação aos homossexuais e estavam dispostos a barrar qualquer tipo de proposta tendente a conceder direitos a esse grupo. Alguns discursos, se fossem pronunciados nos dias de hoje, certamente seriam enquadrados como homofóbicos, de tão carregados de preconceito contra as minorias sexuais.

Para alguns deputados constituintes a inclusão da proibição de discriminação por orientação sexual iria estimular a libidinagem, a imoralidade e a devassidão, introduzindo "maus costumes, entre nós, que só serviriam para perverter a ordem pública, os bons costumes e a moral", além de expor "a sociedade a exageros" e ridicularizar as instituições. E mais:

No Rio de Janeiro e em várias outras partes do Brasil, vemos homossexuais vestidos e pintados como mulher. É uma liberdade, mas que fiquem por lá. Ainda assim, não se muda sua origem masculina, a não ser que façam uma operação. No início, no nascimento, foram registrados como homens. Quanto a esta parte, não estamos discutindo se essas pessoas andam aos grupos - homens homossexuais, mulheres lésbicas etc. Esse é um problema de cada um. O que estou discutindo é que não se deve colocar no texto da nossa Constituição essa aberração (FERREIRA, 1987, p. 34).

O curioso é que depois de dizer tudo isso o nobre deputado concluiu com as seguintes palavras:

Precisamos de uma Constituição séria, em que não sejam inseridas brincadeiras que nos ridicularizem, mas que enalteça o alto espírito do homem público, protegendo a moral em nossa Pátria, os bons costumes da ordem pública, enfim, a dignidade desses princípios. Com esses meus comentários não me refiro a $\mathrm{A}$ ou B. Estou apenas defendendo um ponto de vista, como os demais constituintes, porque acredito que cada um de nós aqui está para fazer um trabalho bem feito em benefício de todos, sem discriminar ninguém (FERREIRA, 1987, p. 34).

Outro deputado foi ainda mais direto quanto ao preconceito:

Quando V. Ex. a estava falando sobre os homossexuais, lembramos que, lamentavelmente, a Câmara Municipal de Salvador, como se sabe - isto foi noticiado pelos jornais - reconheceu, há pouco tempo, um grupo de gays como de utilidade pública. Agora vejam bem, Srs. Constituintes, para onde se está caminhando! Se pelo menos aquela casa legislativa se preocupasse em criar um centro 
de recuperação ou de reintegração dos homossexuais à sociedade eu estaria de acordo, pois, sem dúvida, isto seria um beneficio e uma proteção para eles. Mas, simplesmente legalizar suas atitudes, acredito que é uma distorção da realidade! Tenho em mãos o jornal O Globo, que noticia que, de mil e duzentos presos na $5^{\text {a }}$ Delegacia do Rio de Janeiro, cem estão infectados pelo vírus da aids. O galpão da $5^{\text {a }}$ Delegacia, segundo o Desipe, possui um grande número de detentos homossexuais. Então, a aids - isto é indiscutível - e uma maldição resultante, até, desses desvios sexuais. Aqui fica, mais uma vez, nossa advertência. Ao lado de V. Ex. a, sou contrário a que se mantenha no texto constitucional a expressão 'orientação sexual', que abre um leque para todo tipo de imoralidade (JESUS, 1997, p. 87).

O deputado Costa Ferreira também manifestou a mesma preocupação, assinalando que "se aprovarmos isso [a proibição de discriminação por orientação sexual], aí é que esta Nação vai acabar-se, rapidamente, com a epidemia da aids infectando todo o mundo". E mais:

Se a expressão 'orientação sexual' for mantida aqui, no texto do Anteprojeto, haverá devassidão total. Sem isto, ela já está por aí! Todo mundo tem liberdade! O homossexual masculino sai por aí vestido de mulher, com peruca loura, sapato alto e tudo o mais!... Lésbicas saem vestidas de homem, cortam o cabelo, usam barba!... Quem é que está discriminando essa gente? E ainda é preciso colocar essa expressão, "orientação sexual” na Carta Magna, para tudo isso ficar mais ostensivo? Aí, sim, haveria discriminação! Por isso, Sr. Relator, em que pese a sua bondade gostaríamos de apelar a V. Ex. ${ }^{a}$, a fim de que concorde conosco, retirando esta parte de seu trabalho. Com isso não se vai tirar o direito de ninguém. Pelo contrário, será enaltecido o legislador brasileiro. Muito obrigado. (Palmas) (FERREIRA, 1987, p. 88).

O certo é que, na redação final da Constituição de 1988, não foi incluída a proibição expressa da discriminação por orientação sexual, o que demonstra a força dos deputados mais conservadores.

A não inclusão da proibição de discriminação por orientação sexual na redação final da Constituição de 1988 não significa, obviamente, que foi autorizada a discriminação aos homossexuais. O que houve foi uma solução de compromisso: não se mencionou a proibição de discriminação por orientação sexual por se entender que tal proibição já estava implícita na proibição de preconceito de sexo e quaisquer outras formas de discriminação, constante no artigo $3^{\circ}$, inc. IV, da CF/88. Hoje, até mesmo os mais exaltados críticos da homossexualidade reconhecem que não se pode, no Brasil, discriminar os homossexuais ${ }^{12}$.

${ }^{12}$ Costa Ferreira, que, como se viu, foi um dos deputados constituintes mais indignados com a inclusão da expressão "proibição de discriminação por orientação sexual" assinalou: "Deveremos fazer o que há de melhor para todos, sem prejuízo de ninguém. Manter essa expressão seria exagero. Já temos a palavra 'sexo'. Ninguém é discriminado por seu sexo - aí, entendam como quiserem qual é o sexo. Não há necessidade de mais essa expressão 'orientação sexual' em nosso texto, apesar de todo nosso respeito àqueles que defendem sua permanência" (trecho de discurso do deputado constituinte Costa Ferreira, na Comissão de Soberania e dos Direitos e Garantias do Homem e da Mulher). 
Essa questão foi bem compreendida pelo constituinte Paulo Bisol, que foi um dos maiores defensores da inclusão, no texto constitucional, da proibição de discriminação por orientação sexual. Ele disse, com razão, que o fato de a referida proibição ser incluída ou não no texto constitucional era, de certo modo, irrelevante, pois a discriminação já estaria proibida de qualquer jeito, a não ser que expressamente fosse autorizada. Vale conferir a passagem a seguir, que, a meu ver, sintetiza com perfeição o espírito da Constituição de 1988 nessa matéria. A citação é longa, mas esclarecedora:

Iniciando a apreciação das observações feitas a respeito do Relatório, quero tomar uma questão lógica como o primeiro problema a ser resolvido. Não basta levantar uma questão; é preciso que ela comporte uma decisão lógica, uma modificação lógica. Vou dar um exemplo: orientação sexual. A palavra está ali, objetivamente, e tem esse sentido, isto é, já está popularizada no sentido de que não se faça discriminação quanto aos homossexuais. Os homossexuais são uma minoria na sociedade brasileira. $\mathrm{O}$ artigo visa proibir as discriminações que prejudicam as minorias. Tenho aqui um pequeno livro de ética, escrito por William Froukena [na verdade, o nome do filósofo é Frankena], norte-americano e professor na Universidade de Michigan. Neste livro há esta frase - porque a ética também tem obrigação de ser lógica: 'Um juízo particular vincula essencialmente o juízo geral. De modo que não se pode considerar justificado um juízo particular, a menos que se aceite o juízo geral implicado, e vice-versa'. Quer dizer, um juízo geral implica também o particular. Se estou relacionando as discriminações, não posso retirar do juízo geral discriminação alguma $\mathrm{V}$. Ex. ${ }^{a}$ não acham isso lógico? Se, por exemplo, estou dizendo que é proibida a discriminação sobre sexo, não posso retirar a proibição da discriminação sobre a orientação sexual, pois na verdade, isto já está implicado no juízo geral. Então, se eu retirar reparem bem - do juízo geral, só posso retirá-lo por exceção. Então, não estou admitindo discriminações entre pessoas ou entre grupos. Porém, de repente, quero discriminar um grupo, o dos homossexuais. Quem quiser discriminar este grupo terá que achar uma saída para essa questão lógica. Ela é uma aporia lógica. E vou dizer qual é a saída. Tem que apresentar emendas, mais ou menos, nesse sentido: 'É permitida a discriminação dos homossexuais'. Sejamos moralmente responsáveis. Se quiserem retirar a orientação sexual do juízo geral da proibição das discriminações tirem-na, mas por exceção, não por manejos obscuros e caminhos tortuosos! Estamos perante a História. E o que está sendo dito e escrito, em termos de emendas, de projetos, de votos, vai ficar na História, sob responsabilidade nominal e individual. Colocarei no relatório, se houver a emenda: 'A lei permitirá a discriminação dos homossexuais'. E se esta emenda for aprovada, eu a inserirei no texto, mas sem assunção moral da sua responsabilidade. Não posso modificar o Relatório neste particular, porque sou contra um dispositivo que cria a proibição da discriminação e faz, ao mesmo tempo, uma discriminação! O que é um absurdo lógico! A questão não é moral; é lógica, e simplesmente lógica! Não são válidos - e digo mais - não são moralmente válidos os argumentos que felizmente, hoje à tarde não aconteceram, mas foram empregados hoje, pela manhã no sentido de que estou abrindo as portas da libidinagem, ao colocar expressão a 'orientação sexual', 
ou o homossexualismo como uma minoria que não deve ser discriminada. Este argumento da libertinagem é um falso argumento. Mas, tão flagrante e evidentemente falso que acho que a paixão pelo problema está obscurecendo a visão das pessoas relativamente a uma evidência. O argumento é este: o Relator está permitindo, nas repartições públicas, a cópula anal entre dois homens, a relação sexual entre duas mulheres, a fellatio. Mas, meus amigos, antes da orientação sexual é proibida a discriminação em razão de sexo. O fato de proibirmos a discriminação de sexo legitima a relação heterossexual nas repartições públicas? Que espécie estranha de raciocínio é este? Não! A boa fé está mostrando que os atos heterossexuais praticados em lugares inadequados serão punidos pela lei e que os atos homossexuais praticados era lugares inadequados serão punidos pela lei. O que vale para um vale para o outro! Acho que está faltando - digo isso com humildade - um pouco de lógica no raciocínio, está faltando um pouco de aprofundamento. Mas, repito, se apresentarem uma emenda honesta, dizendo que a lei permitirá a discriminação dos homossexuais, e se ela passar na votação, eu a acrescentarei. Só que eu vou registrar que não foi por minha culpa, é claro não vou carregar perante a História esta responsabilidade (BISOL, 1987, p. 79).

Parece-me bastante óbvio o que Paulo Bisol desejou assinalar: os conservadores estavam criticando a inclusão no texto constitucional da expressa proibição de discriminação por orientação sexual, mas não tinham coragem de defender expressamente a autorização para que os homossexuais fossem discriminados. Assim, apesar de toda a polêmica em torno dessa questão, que gerou gritos de indignação dos parlamentares mais conservadores, é inegável que a Constituição Federal de 1988, embora não tenha previsto a proibição de discriminação por orientação sexual, não autorizou a discriminação aos homossexuais.

Até aqui, creio eu, a minha interpretação da história constituinte não gera maiores polêmicas. A controvérsia central, porém, não gira em torno da proibição de discriminação por orientação sexual, mas sim do reconhecimento das uniões estáveis homoafetivas, que também foi alvo de muitos debates constituintes. Havia, na verdade, dois debates: (a) a própria equiparação das uniões estáveis ao casamento e (b) a extensão da noção de união estável às relações homoafetivas.

Os parlamentares mais conservadores não queriam sequer que as uniões estáveis fossem protegidas. Para muitos deputados constituintes, o casamento seria a única forma legítima de constituição de família ${ }^{13}$. A maioria,

${ }^{13}$ Confira-se, por exemplo, este discurso: "Sr. Presidente e Sr. Relator, continuando as observações que fiz na parte da manhã, gostaria de solicitar a especial atenção do Sr. Relator para alguns enunciados fundamentais que $\mathrm{S}$. Ex ${ }^{\mathrm{a}}$ coloca na versão preliminar de seu trabalho, relacionados com alguns itens que lentamente vamos descobrindo pela frente. Por exemplo, quanto à forma como S. Ex define a família. O item XVIII me revela que se foge ao padrão normal de família constituída, pois diz que é garantida a constituição de família pelo casamento e depois, por união estável baseada na igualdade entre homem e mulher. Acho que nem toda união estável pode significar família. Essa igualdade entre homem e mulher, não sei se é básica. Não entendi bem, e fiquei na dúvida. Daí o questionamento que faço. Isto porque, de modo geral, entende-se o que seria a união estável entre um homem e uma mulher - se bem que não está definido. Fico preocupado com esse avanço na definição de família. Foge aos padrões do Cristianismo. 
contudo, preferiu aprovar a equiparação das uniões estáveis às uniões matrimoniais, seguindo a evolução natural da sociedade que, já naquela época, começava a aceitar as relações afetivas informais "sem papel passado".

O debate, porém, prosseguiu para o nível seguinte: o que pode ser considerado como união estável? Não houve, até onde sei, nenhum parlamentar que defendesse abertamente o casamento gay. O tema, na época, era ainda um tabu e, pelo que se viu em torno dos debates sobre o problema da "discriminação por orientação sexual", já se pode perceber que havia pouco ou nenhum espaço para um avanço tão grande nessa seara. Nem mesmo os deputados simpáticos à causa dos homossexuais defenderam abertamente o casamento gay ou mesmo a união estável homoafetiva. A esse respeito, pode-se colher o seguinte trecho de um discurso de Paulo Bisol que, como se viu, era favorável aos direitos dos homossexuais:

Quanto ao problema da família, o nobre Constituinte estranhou a expressão 'união estável', como se ela incluísse a possibilidade de uniões entre homossexuais. Nobre Constituinte, não estou preocupado com as uniões dos homossexuais. Se eles querem fazer, que as façam! Desde que isto não se converta num escândalo social, é um direito deles. A palavra 'casamento' também não evita, em si mesma essa expressão. Porque eles falam em casamento! Tenho lido nos jornais e até ouvi um Constituinte, aqui, falar: 'Estamos permitindo casamento de homossexuais?' Meu Deus, não se trata disso! Apenas se trata de dizer que os homossexuais são seres humanos! E aqui disseram até que é uma questão de nascimento. Não vou a tanto. Acho que é mais um problema cultural e de formação. Mas, não entro em discussão. O que eu quero dizer é que os homossexuais não me perturbam. Acho que eles são pessoas humanas. E creio que ninguém tem o direito de não empregar um homem competente por ser ele um homossexual! É isto. Aqui argumentaram que eu estava colocando a expressão 'orientação sexual' no sentido de autorizar a cópula homossexual, por exemplo, dentro de um quartel. Mas, meu Deus, dentro de um quartel, um lugar inadequado, a cópula homossexual é uma transgressão disciplinar! Entenderam? Será que não é simples isso? Qualquer cópula num lugar inadequado, ou em público, é uma transgressão disciplinar. Não estou autorizando essa transgressão disciplinar. Agora. V. Exas. me desculpem, mas, na intimidade deles, eles farão o que quiserem, porque nós na nossa heterossexualidade, fazemos. $\mathrm{Ou}$ não fazemos! Porque somos livres! Que negócio é esse de restringir a liberdade dos outros, quando eles não afetam a nossa liberdade? Não é este o discurso de todos, ou seja, que todo mundo é livre naquilo que não afeta os outros? A mim a homossexualidade dos outros não afeta. Não sei se os Constituintes se sentem

E o Brasil é um País de cristãos, em sua maioria. Devemos, realmente. respeitar o costume da maioria, que é o de constituir família por contrato civil, dentro das normas já estabelecidas na lei ordinária, ou, quando constituída a sociedade entre um homem e uma mulher através da igreja a que pertencem, seja esse contrato levado a registro para os efeitos civis. Fugir daí é um avanço muito grande, que redunda em retrocesso na disciplina da célula mater de qualquer sociedade, que é a família. Vemos, hoje, a televisão solapar, por todos os meios imagináveis e inimagináveis as bases da família, tentando destruí-la, para acabar com o conceito de fidelidade àquilo que assumimos" (trecho de discurso do constituinte José Mendonça Morais na Comissão de Soberania e dos Direitos e Garantias do Homem e da Mulher). 
afetados pela homossexualidade dos outros. A mim, não afeta. E eu conheço homossexuais tremendamente responsáveis, pessoas de caráter, inteligentes, com capacidade de trabalho! E nutro por eles o mais profundo respeito! Porque não sou o modelo de ninguém. A minha heterossexualidade é uma pessoal, não afeta ninguém. Eu resolvo. E, se alguém não quiser ser heterossexual, tem esse direito, não vai me incomodar (BISOL, 1987, p. 59).

Mas, ao mesmo tempo, ele arrematou:

Então, a união estável, por suposição natural, é entre o homem e a mulher, nobre constituinte. Nem me passa pela cabeça legislar sobre as outras. Repito: casamento não seria uma palavra que evitaria esse tipo de união homossexual. Acho, pois, que não há o que retificar aí (BISOL, 1987, p. 59).

Esse tema, portanto, não gerou um debate parlamentar mais intenso, já que o casamento gay não estava em pauta ("nem passou pela minha cabeça", disse Paulo Bisol) e não havia, a rigor, qualquer constituinte disposto a defender ferrenhamente essa tese. O que foi discutido e decidido foi a aprovação da equiparação da união estável ao casamento.

Apesar de o texto do anteprojeto até então aprovado não se referir à união estável homoafetiva, vários setores da sociedade chegaram a sugerir que, uma vez equiparada a união estável entre homem e mulher ao casamento, estar-se-ia abrindo a possibilidade para o reconhecimento das uniões estáveis entre pessoas do mesmo sexo e, para muitos parlamentares, isso seria um escândalo. Para evitar esse tipo de interpretação do texto constitucional, um grupo de parlamentares propôs a inclusão dos artigos "o" e "a" ("união estável entre $o$ homem e $\boldsymbol{a}$ mulher") na redação final da Constituição de 1988, e a tese acabou prevalecendo.

A síntese desse debate pode ser extraída da seguinte passagem:

O SR. CONSTITUINTE GASTONE RIGHI:-Finalmente a emenda do Constituinte Roberto Augusto. É o Artigo 226, § $3^{\circ}$ Este parágrafo prevê: "Para efeito da proteção do Estado, é reconhecida a união estável entre homem e mulher como entidade familiar, devendo a lei facilitar sua conversão em casamento." Tem-se prestado a amplos comentários jocosos, seja pela imprensa, seja pela televisão, com manifestação inclusive de grupos gays através do País, porque com a ausência do artigo poder-se-ia estar entendendo que a união poderia ser feita, inclusive, entre pessoas do mesmo sexo. Isto foi divulgado, por noticiário de televisão, no show do Fantástico, nas revistas e jornais. O bispo Roberto Augusto, autor deste parágrafo, teve a preocupação de deixar bem definido, e pede que se coloque no $\S 3^{\circ}$ dois artigos: "Para efeito da proteção do Estado, é reconhecida a união estável entre o homem e a mulher, como entidade familiar, devendo a lei facilitar sua conversão em casamento". Claro que nunca foi outro o desiderato desta Assembléia, mas, para se evitar toda e qualquer malévola interpretação deste austero texto constitucional, recomendo a V. Ex. ${ }^{a}$ que me permitam aprovar pelo menos uma emenda. 

ao Relator.

O SR. PRESIDENTE (Ulysses Guimarães): Concedo a palavra

O SR. CONSTITUINTE GERSON PERES: - A Inglaterra já casa homem com homem há muito tempo.

O SR. RELATOR (Bernardo Cabral): - Sr. Presidente, estou de acordo.

O SR. PRESIDENTE (Ulysses Guimarães): - Todos os que estiverem de acordo permaneçam como estão. (Pausa) Aprovada. (Palmas).

Aparentemente, a narração da história constituinte até aqui poderia servir para criticar a decisão do STF. Afinal, se tomarmos como parâmetro a vontade manifestada na passagem anterior, parece claro que a intenção dos constituintes não era permitir a união estável entre pessoas do mesmo sexo. Como então justificar a decisão do STF? Não teriam, de fato, os ministros da mais alta corte violado os "limites semânticos da Constituição", como defendeu Lênio Streck? Não teriam os ministros substituído as preferências dos constituintes pelas suas próprias preferências pessoais, arvorando-se no papel de poder constituinte derivado sem legitimidade para tanto?

A resposta a essa questão não é fácil, pois pressupõe a construção de uma intricada teoria de interpretação constitucional, além de um aprofundamento em alguns temas de filosofia política e filosofia moral, o que certamente não caberia nos estreitos limites de um artigo despretensioso como este. Portanto, vou abordar apenas alguns aspectos de mais fácil compreensão a fim de defender a solução adotada pelo Supremo Tribunal Federal. Ao invés de entrar na delicada questão de saber qual é a melhor forma de interpretar a Constituição, ficarei no básico das teorias hermenêuticas, sem fugir da tradicional ideia de que interpretar é obter o melhor sentido do texto. Também evitarei desenvolver qualquer tipo de solução mais sofisticada, envolvendo, por exemplo, o controle de convencionalidade de normas constitucionais, em que os tratados internacionais que proíbem a discriminação poderiam ser invocados para anular o texto constitucional. Evitarei, do mesmo modo, desenvolver qualquer teoria mais sofisticada sobre a inconstitucionalidade das normas constitucionais, sugerindo a prevalência de princípios de justiça superiores que poderiam ser invocados para incluir os homossexuais no mesmo patamar de dignidade atualmente reconhecida aos heterossexuais. Creio que nada disso é necessário no presente caso.

Também poderíamos partir para uma estratégia argumentativa mais radical, questionando a própria legitimidade da assembleia constituinte ou pelo menos daqueles setores mais conservadores, que teriam usurpado o poder popular usando a religião para arregimentar eleitores. Ou então dizer que a democracia representativa possui falhas intrínsecas que deturpam a vontade geral, e 
que, portanto, caberia ao órgão de jurisdição constitucional corrigir as distorções desse modelo, sobretudo para proteger os grupos politicamente enfraquecidos contra o preconceito da maioria. Esse discurso radical tem o seu fundo de verdade, mas certamente não convenceria os juristas mais tradicionais, que jamais seriam capazes de colocar em dúvida a autoridade da Constituição. Como a minha pretensão é dialogar até mesmo com os juristas mais conservadores, partirei do senso comum de que a Constituição é a norma suprema e todos, sobretudo os membros do Judiciário, devem obedecê-la incondicionalmente e zelar pela sua integridade. Sendo assim, tentarei desenvolver uma proposta interpretativa que não fuja dos "limites semânticos da Constituição", usando apenas os pressupostos clássicos do pensamento jurídico, ainda que, a meu ver, eles nem sempre sejam adequados para solucionar casos difíceis.

\section{O QUE ESTÁ EM JOGO?}

De início, é preciso saber o que está, de fato, em jogo nessa questão, porque certamente não se trata de uma discussão meramente abstrata, nem apenas de uma briga de egos pelo rótulo "família". O resultado desse debate definirá, em última análise, se os casais homoafetivos merecerão a mesma proteção jurídica conferida aos casais heteroafetivos. O que está em jogo, portanto, é saber que direitos os homossexuais são merecedores quando resolvem formar uma união contínua e assumir compromissos duradouros entre si.

Pessoas casadas ou vivendo em união estável heteroafetiva recebem do Estado vários direitos que não são estendidos a pessoas solteiras e, até então, não eram estendidos a casais homoafetivos. A possibilidade de deduções no imposto de renda é maior; há o direito de recebimento de pensão de morte quando houver o falecimento de um dos cônjuges; o plano de saúde familiar é mais barato; em caso de morte, a transmissão dos bens para o cônjuge sobrevivente é mais fácil; no direito administrativo, o servidor público pode acompanhar seu cônjuge ou companheiro em caso de transferência ou remoção ex officio, bem como obter licença para tratamento de saúde do companheiro/ cônjuge, e assim por diante. Há, naturalmente, em contrapartida, os ônus e deveres próprios de uma relação familiar, inclusive de índole patrimonial, como o dever de prestar alimentos ao dependente em caso de separação, comunhão dos bens adquiridos pelo casal e as demais responsabilidades próprias da uma relação familiar.

Vale ressaltar que, muito antes da decisão do Supremo Tribunal Federal, essas questões já vinham sendo decididas pelas instâncias ordinárias da justiça brasileira e, de forma quase pacífica, os direitos dos homossexuais vinham sendo reconhecidos judicialmente. Há pelo menos uns quinze anos a ju- 
risprudência nacional equiparava a união estável homoafetiva às uniões estáveis heteroafetiva para inúmeros fins sem que isso gerasse tamanha polêmica ${ }^{14}$. Raras eram as decisões em sentido contrário. A decisão do STF teve o efeito apenas de permitir que tais direitos fossem concedidos independentemente de ação judicial, pacificando a questão a favor dos homossexuais. As críticas, portanto, sobretudo aquelas que beiram a histeria, alarmando contra um ativismo judicial desenfreado e inconsequente, parecem exageradas se olhadas nesse contexto, já que o STF nada mais fez do que consolidar uma jurisprudência pacificada pelas instâncias ordinárias.

Outro direito polêmico, que tem gerado uma grande indignação retórica por parte dos que são contrários aos direitos dos homossexuais, esconde um falso problema jurídico. Refiro-me à adoção de crianças por casais homoafetivos. Atualmente, o Código Civil autoriza que uma pessoa solteira, independentemente de opção sexual, adote uma criança. Então, na prática, os homossexuais já vinham adotando crianças normalmente na qualidade de pessoas solteiras, incluindo apenas um dos membros do casal como adotante. A decisão do STF também não revoluciona essa questão, pois apenas vai permitir que, de agora em diante, os dois membros do casal homoafetivo possam adotar ao mesmo tempo, o que certamente dará uma proteção ainda maior à criança ${ }^{15}$.

Como se vê, existem várias vantagens jurídicas em constituir família, pois essa condição habilita a entidade familiar a receber uma série de benefícios materiais, econômicos e não econômicos, por parte do Estado. Há benefícios fiscais, sociais, sucessórios, administrativos, previdenciários, entre inúmeros outros. É um equívoco achar que o que está em jogo é apenas o direito de usar o rótulo de entidade familiar ou de ter as suas disputas de relacionamento regidas pelo direito de família e não pelo direito das obrigações. Há muito mais direitos em jogo. A questão é saber se essas vantagens podem ser negadas aos casais entre pessoas do mesmo sexo que vivem junto, em união duradoura e estável, já que as uniões estáveis heteroafetivas gozam das mesmas vantagens dadas às uniões matrimoniais formalizadas pelo casamento.

${ }^{14}$ Em matéria previdenciária, por exemplo, desde o ano 2000, o INSS, em cumprimento a uma ordem judicial do Tribunal Regional Federal da $4^{\text {a }}$ Região (Proc. 2000.71.00.009347-0), já havia sido obrigado a reconhecer a validade das uniões homoafetivas, tendo regulamentado a questão administrativamente, por instrução normativa (IN 45/2000), para estender aos casais homoafetivos os direitos previdenciários assegurados aos casais heteroafativos (pensão por morte e auxílio-reclusão).

${ }^{15}$ Ressalte-se que a jurisprudência, inclusive do Superior Tribunal de Justiça, já vinha reconhecendo que os casais homossexuais poderiam adotar crianças, na condição de entidade familiar equiparada à união estável, baseando-se, sobretudo, no princípio de melhor proteção aos direitos da criança: STJ, REsp 889.852/RS, Rel. Ministro LUIS FELIPE SALOMÃO, QUARTA TURMA, julgado em 27/04/2010, DJe $10 / 08 / 2010$. 


\section{Interpretando A Constituição}

Há, pelo menos, três enunciados constitucionais relevantes para a correta solução do problema: (a) a proibição de discriminação (artigo $3^{\circ}$, inc. IV); (b) a proteção jurídica à família (artigo 226); (c) o reconhecimento da união estável entre o homem e a mulher como entidade familiar (artigo 226, $\S 3^{\circ}$ ). Deixarei aqui de incluir outros artigos igualmente relevantes, inclusive de tratados internacionais ou normas de índole principiológica (dignidade, solidariedade, justiça, laicidade do Estado etc.), porque para rebater as críticas ao julgamento do STF é suficiente mirar apenas nesses três dispositivos.

A pergunta central da discussão pode ser formulada de duas maneiras:

1. As uniões estáveis entre pessoas do mesmo sexo podem ser reconhecidas como entidade familiar equiparadas ao casamento para fins de proteção jurídico-estatal, do mesmo modo que são protegidas as uniões estáveis entre homem e mulher?

2. A legislação infraconstitucional pode adotar medidas de discriminação negativa em relação aos casais homoafetivos, negando a esses casais benefícios concedidos aos casais heteroafetivos que vivem em união estável?

Os críticos costumam formular apenas a questão número 1 . E rapidamente respondem-na com um sonoro não, invocando, para tanto, a "intenção original do constituinte brasileiro" ou a "vontade da Constituição", seja lá o que isso significa. Assim, a segunda questão é respondida apenas implicitamente, como se a discriminação dos homossexuais decorresse naturalmente da leitura do texto constitucional e fosse fruto de uma vontade inquestionável de um ente supostamente real chamado "constituinte".

Muitos juristas que seguem essa linha baseiam-se em uma teoria interpretativa que pode ser designada como intencionalismo ou interpretativismo. Segundo essa perspectiva, o juiz deve interpretar os textos jurídicos conforme a intenção daqueles que os elaboraram no momento de sua aprovação. Assim, a solução dos problemas jurídicos, mesmo daqueles que envolvam a correta interpretação de um texto, seria uma questão de fato: caberia ao jurista investigar empiricamente a intenção daquela autoridade que editou a norma, a fim de descobrir a sua vontade autêntica.

Vários são os juristas que, a seu modo, defendem que o juiz deve interpretar a lei de acordo com esse método. Savigny, por exemplo, dizia que o intérprete da lei deveria "se colocar na posição do legislador e deixar que se formem, por esse artifício, os respectivos ditames". Windscheid, do mesmo modo, defendia que o jurista deveria buscar, na interpretação das leis, o sentido que "o legislador ligou às palavras por ele utilizadas" e executar o pensamento do legis- 
lador, levando em consideração tanto as circunstâncias jurídicas que estiveram presentes no seu espírito quando ditou a lei quanto os fins por ele perseguidos. Schönfeld, de igual modo, sustentava que a integração do direito deveria ocorrer "segundo o espírito e o sentido da lei na qual se encontra", devendo o juiz atuar como uma espécie de representante do legislador. Philipp Heck e os adeptos da "jurisprudência dos interesses" exortavam os juízes a investigarem as valorações do legislador e a aplicarem os mesmos juízos de valor contidos na lei (sobre essas teorias: LARENZ, 1994).

No âmbito do Direito Constitucional, o intencionalismo costuma ser designado, sobretudo na cultura anglo-saxã, de originalismo, que tem como premissa a ideia de que a Constituição tem um sentido fixo, estabelecido no momento de sua promulgação por aqueles que a elaboraram (os norte-americanos usam a expressão founding fathers para se referirem aos fundadores do país). Dentro dessa perspectiva, caberia aos juízes, ao interpretarem a Constituição, tentarem descobrir a intenção subjetiva dos fundadores do país a partir de uma investigação dos debates parlamentares desenvolvidos na ocasião da aprovação do texto, a fim de tentar captar o que os seus autores tinham em mente quando o redigiram ou então o sentido razoável do texto na época de sua promulgação.

Essas propostas metodológicas têm dois argumentos de peso a seu favor: em primeiro lugar, preocupam-se com os princípios da democracia e da separação de poderes, já que o Judiciário estaria seguindo exatamente as instruções pretendidas pelo parlamento; em segundo lugar, tentam tornar a atividade judicial mais objetiva e politicamente neutra, no sentido de que os juízes não estariam julgando com base em suas próprias preferências pessoais, mas sim com base nas preferências dos legítimos representantes do povo.

Apesar disso, é possível formular várias objeções a esse método de raciocínio jurídico ${ }^{16}$. Em primeiro lugar, não existe algo como $o$ legislador ou $o$ constituinte, pelo menos nas democracias modernas, marcadas por vontades plurais e ideologicamente diversas. O que existe é um grupo de parlamentares responsáveis por aprovar as leis ou a Constituição, dentro de um processo legislativo complexo, imprevisível e volátil, onde diversos fatores contingenciais influenciam a formação da vontade. Raramente, há unanimidade entre os congressistas, pois cada parlamentar está representando interesses específicos que, em geral, são contraditórios e inconciliáveis. O "legislador" ou o "constituinte", como algo real e personificado, pelo menos nas democracias modernas, não é um ser real, com uma vontade única e com um único interesse a ser levado em conta, mas vários políticos com visões e interesses bem diferentes entre si.

${ }^{16}$ Baseio-me aqui em alguns argumentos por mim desenvolvidos, mas também presentes em DWORKIN, 2001, PP. 471/474. 
E, mesmo que houvesse um único legislador, seria bastante difícil abrir o seu cérebro para analisar seus pensamentos conscientes e inconscientes. Ainda não desenvolvemos uma tecnologia suficientemente avançada que permita, de forma telepática, ler a mente de outras pessoas. Por isso, saber o que se passou na cabeça de cada um dos membros da assembleia constituinte quando foi aprovado o texto constitucional significa, na maioria das vezes, entrar em um jogo de adivinhação sem qualquer base racional, até porque a vontade dos parlamentares é dinâmica, pois o jogo político não segue uma lógica cartesiana, onde sempre vence a solução mais racional. No debate parlamentar não há uma obrigação absoluta de coerência: um parlamentar pode ser a favor de uma tese em um dado momento e, no dia seguinte, pode mudar de lado conforme a conveniência política.

Tente, por exemplo, imaginar o que se passou na cabeça de cada deputado constituinte no momento em que o Presidente da Assembleia Constituinte afirmou que "aqueles que concordam com a alteração do artigo $226, \S 3^{\circ}, \mathrm{da} \mathrm{CF} / 88$, para incluir a expressão 'entre o homem e a mulher' permaneçam como estão". Esse momento não deve ter durado nem dez segundos. Que tipo de ponderações mentais influenciou a decisão de todos os deputados, até mesmo daqueles que eram favoráveis aos direitos dos homossexuais? Todos estavam conscientes e desejavam que os casais homoafetivos fossem discriminados? Será que todos compreendiam todas as consequências futuras que aquela deliberação poderia vir a ter? O horário da votação influenciou o resultado? A fome e o desejo de terminar aquela votação o mais rápido possível para poder descansar teve alguma relevância na tomada de posição? A influência da liderança do partido induziu alguém a votar? Houve acordos de bastidores, que, possivelmente, alterariam a vontade real de cada parlamentar? Como extrair desse jogo mental uma vontade autêntica e unívoca, sobretudo quando o texto não é tão explícito quanto à permissão para a discriminação dos homossexuais?

A deferência judicial ao interpretar a Constituição conforme a intenção dos membros da Assembleia Constituinte é salutar, mas muito difícil de ser operacionalizada na prática. Como assinalou Dworkin, "se a intenção legislativa busca permanecer fiel aos princípios democráticos, uma exigência mínima deve ser satisfeita: um número suficiente dos que votaram a favor de uma lei deve ter uma compreensão comum, de modo que esse número sozinho pudesse ter aprovado a lei, mesmo que todos os outros - os que não compartilhavam dessa compreensão - tivessem votado contra". Daí porque "a ideia de uma compreensão legislativa coletiva é de uso limitado", já que "é muito difícil para um tribunal descobrir, anos após o fato, qual foi a compreensão de algum legislador específico, de modo que é difícil saber qual foi a intenção proposta" (DWORKIN, 2001, pp. 480/481).

Nem sempre é possível interpretar a Constituição seguindo a vontade original dos constituintes, até porque há vários constituintes com opiniões 
conflitantes dentro da mesma assembleia e muitos deles sequer tinham ideia de como seria a sociedade brasileira vinte anos depois, nem poderiam prever todas as consequências futuras de sua opção. Caso seja adotada essa ideia de que o juiz deveria buscar a intenção originária dos deputados constituintes, surgiriam várias dúvidas daí decorrentes: os juízes deveriam agir como os constituintes do bloco majoritário ou de algum bloco minoritário? Como parlamentares de direita ou de esquerda? Liberais ou conservadores? Deve-se levar em conta apenas as opiniões dos parlamentares com algum papel de liderança ou também vale a opinião dos deputados sem qualquer expressão política? Deve-se buscar as intenções dos constituintes do presente (como eles pensam hoje) ou do passado (como eles pensavam quando votaram a Constituição)?

Creio que ninguém sugeriria qualquer uma dessas opções de forma taxativa, já que ninguém espera de um julgador que tome partido sobre uma determinada questão movido primordialmente por suposições místicas. Os interesses que causaram a lei devem, sem dúvida, ser levados em conta pelo juiz, mas não como critério absoluto de julgamento, até porque a interpretação da lei depende do contexto e o contexto muda com o passar do tempo. Os critérios da decisão judicial devem ser baseados em uma concepção de imparcialidade onde o interesse de todos os envolvidos seja tratado com igual respeito e consideração, especialmente porque a Constituição de 1988 é toda alicerçada nessa ideia ${ }^{17}$.

Mas, para que o debate prossiga, vamos conceder, pelo menos para fins argumentativos, que, se for possível descobrir a intenção originária dos constituintes, os juízes deveriam segui-la incondicionalmente, por mais tola e preconceituosa que seja essa vontade. Particularmente, não penso que deva ser assim, pois acredito que o método originalista não é o melhor método de interpretação da Constituição. Apesar disso, argumentarei dentro dessa linha de raciocínio a fim de poder dialogar com os críticos.

\section{F. Qual Era a Autêntica Intenção dos Constituintes?}

De início, é preciso reconhecer a plausibilidade da tese de que a intenção original de alguns constituintes (talvez da maioria) fosse, de fato, negar aos homossexuais qualquer tipo de direito relacionado à família. A análise dos debates constituintes pode levar a esse entendimento.

Mas essa plausibilidade não é tão clara e inquestionável quanto aparenta à primeira vista. Foram poucos deputados constituintes (menos de dez) que discursaram expressamente sobre o assunto, e seus discursos ou são

17 Obviamente, estou aqui invocando, de um modo bastante simplificado, a proposta de Ronald Dworkin, que é um ferrenho crítico do originalismo interpretativo. 
notoriamente contrários ao que foi aprovado ou não são expressos quanto à possibilidade de discriminação negativa aos casais homoafetivos. Como se viu, houve deputados que foram contrários à própria união estável como um todo e certamente não foi essa a intenção prevalecente. Outros defendiam, bem ao estilo da lógica NIMBY ${ }^{18}$, até mesmo a proibição de manifestações homossexuais em lugares públicos ${ }^{19}$, o que também não foi aprovado. Outros eram incoerentes: ora diziam que os homossexuais não podiam ser discriminados, ora diziam que o homossexualismo era uma aberração ${ }^{20}$. Tomar como base essas manifestações isoladas de deputados com pouca expressão política para tentar captar a intenção dos constituintes é tomar a parte pelo todo. Pior: é tomar a parte ruim pelo todo.

Na minha leitura dos fatos históricos, penso que houve um compromisso de cavalheiros com os interesses alheios. Não havia, na assembleia constituinte, ninguém que quisesse comprar, verdadeiramente, uma briga em favor dos homossexuais. Porém, também não havia ninguém que tivesse coragem de incluir, de forma explícita, uma autorização para que os homossexuais fossem perseguidos, discriminados ou menosprezados. A questão, então, foi tratada de forma velada: os conservadores imaginaram que, ao incluírem a expressão "entre o homem e a mulher" automaticamente estar-se-ia negando aos casais homossexuais o direito de serem tratados como entidade familiar. $\mathrm{O}$ texto que passou, a rigor, não diz nada disso. Diz apenas que será reconhecida a união estável entre o homem e a mulher, mas não exclui a possibilidade de reconhecimento das uniões estáveis homoafetivas. Não há, de forma clara, um conceito expresso de entidade

\footnotetext{
${ }^{18}$ NIMBY é um acrônimo inglês de "Not In My Back Yard", que pode ser traduzido como "não no meu quintal". Apesar de ser utilizado por urbanistas para se referirem àquelas construções que ninguém quer ter por perto de sua casa (como os presídios, fábricas poluidoras, usinas nucleares, aterros sanitários etc.), também se aplica com perfeição ao mundo dos direitos fundamentais. Há muita gente que defende a democracia, a liberdade e a igualdade, mas "não no meu quintal", ou seja, defende uma ampla tolerância e abertura para as suas idéias, mas quando se depara com valores pregados por outros grupos simplesmente se nega a aceitar tê-los por perto ou mesmo ouvi-los. A síndrome NIMBY é bastante visível com relação à discriminação por orientação sexual. Muitas pessoas defendem um tratamento igualitário para as minorias sexuais, desde que cada um se mantenha em seu próprio lugar. Também é possível verificar o mesmo fenômeno em assuntos de religião.

19 "Não estamos contra quem tenha desvio sexual! Que pratique seus atos, desde que encontre seus parceiros, e o faça lá, às ocultas, mas não publicamente, de modo cínico, faltando com o respeito à sociedade. Até mesmo no caso do homem e da mulher, que têm o privilégio de se unir publicamente, não em termos de sexo, mas de se abraçarem, de trocarem carinhos, quando o fazem de público já estão sob alguma censura, quanto mais uma pessoa que seja homossexual! Por que não podem ser discriminados, agora podem beijar-se em público?" (trecho do discurso do Deputado Costa Ferreira, na Comissão da Soberania e dos Direitos e Garantias do Homem e da Mulher).

${ }^{20}$ Confira esse trecho do discurso do Deputado Costa Ferreira: "Não aceitamos discriminação de espécie alguma, nem com o idoso, nem com o religioso, nem com o homossexual, mas também não aceitamos, de maneira alguma, que se modifiquem os padrões e os níveis de compreensão para implantar-se uma nova ordem que, por certo, irá liquidar com a estrutura moral deste País". É possível entender a intenção do nobre deputado? E este outro trecho: "não podemos permitir que homossexuais, por exemplo, se casem, quer, dizer, homem com homem, mulher com mulher. Isso seria um desastre. Não se pretende discriminar, mas, sim, proteger a sociedade".
} 
familiar no texto constitucional. $\mathrm{O}$ artigo $226, \S 3^{\circ}$, da $\mathrm{CF} / 88$, diz menos sobre a questão das uniões homoafetivas do que aquilo que os que são contra os direitos dos homossexuais enxergam. Daí porque é impossível dizer se, realmente, a "vontade do constituinte" fosse excluir, de plano, a possibilidade do reconhecimento da união estável homoafetiva. Obviamente, também é impossível dizer que os constituintes desejavam estender a proteção da família às uniões estáveis homoafetivas. Aliás, somente um intérprete muito mal intencionado diria que os constituintes desejaram, sem sombra de dúvidas, equiparar os casais homossexuais aos casais heterossexuais.

A grande chave para a solução do problema não está, portanto, apenas no artigo $226, \S 3^{\circ}$, da $\mathrm{CF} / 88$, mas, sobretudo, na proibição de discriminação por quaisquer motivos, inclusive, é óbvio, por orientação sexual. Penso que a estratégia dos conservadores de achar que bastava incluir no texto constitucional a expressão "entre o homem e a mulher" para evitar qualquer dúvida interpretativa sobre as uniões estáveis homoafetivas foi uma tentativa malograda de discriminar sem sair tão mal na foto. Eles deveriam ter sido mais explícitos, pois uma discriminação tão séria e tão contrária ao restante do texto constitucional, não poderia ser velada. Qualquer discriminação aos homossexuais teria que ser manifesta, o que certamente impediria a aprovação do texto, pois poucos deputados compactuariam com a discriminação explícita. A redação da Constituição, para afastar qualquer dúvida, teria que ser mais ou menos assim: "é proibida a concessão aos casais formados por pessoas do mesmo sexo dos mesmos direitos concedidos aos casais formados entre o homem e a mulher".

Para reforçar essa hipótese, invoco novamente aquela esclarecedora passagem do discurso do deputado Paulo Bisol, onde ele diz, com acerto, que se não fosse aprovada uma expressa previsão constitucional permitindo a discriminação aos homossexuais (e não foi aprovado nada nesse sentido), "o que vale para um [heterossexuais] vale para o outro [homossexuais]". Há outra passagem de seu discurso que segue a mesma ideia e esclarece ainda mais a questão:

Estou entre os que não excluem os homossexuais da humanidade. Estou entre os que respeitam os homossexuais como pessoas. Estou entre os que não querem que eles sejam discriminados. Mas, além desse aspecto, sou democrata. Se a maioria quiser discriminá-los - e eu deixei isso bem claro, ontem - discrimine-os. Nós, aqui, estamos assumindo responsabilidades históricas. Eu assumo a responsabilidade de não discriminá-los. E quem quiser assumir a de discriminá-los, assuma-a. Isto é a liberdade. Se houver maioria, eu me sujeito a ela. Nem acho que isso seja de tanta relevância, mas que os discriminem corajosamente, explicitamente. É um pedido de natureza moral. Querem discriminá-los, discriminemos. Escrevam e assinem! (...) Será que não dá para entender que, de repente, eu digo que e proibido discriminar as minorias e, no entanto, não quero que incluam lá, no texto exemplificativo, a orientação sexual? Por quê? Não é 
para proibir essa discriminação? Os que estão preocupados com este problema, que não me parece relevante, a não ser no sentido ético, têm que me explicar. Estou aqui para ser convencido. O que é que desejam? Querem que eu ponha no anteprojeto que a lei permitirá a discriminação por orientação sexual? É isso que pretendem? Mas, então, está faltando clareza! Peçam isso, discutam isso!

Ontem sugeri - e volto a sugerir: o dispositivo que proíbe a discriminação, quando faz referência aos elementos geradores da discriminação, é exemplificativo, não é exaustivo. Mesmo que não se falasse em sexo, a discriminação de sexo estaria proibida. Mas, como temos problemas culturais, insiste-se, redunda-se, aprofunda-se a exigência. Sugiro, portanto, que aqueles que querem fazer uma exceção na proibição da discriminação que o façam. Nossa idéia é democrática. Acho eu que a idéia democrática do povo brasileiro é a de que não haverá discriminação de espécie alguma. Agora, se o povo brasileiro quiser eliminar uma discriminação, legitimar uma discriminação, então, que me apresente uma emenda, que tem que ser mais ou menos nestes termos: 'a lei permitirá a discriminação de homossexuais’. É uma questão lógica! (BISOL, 1987, p. 93).

Pela leitura dessa passagem, observa-se que os constituintes tinham plena consciência de que qualquer discriminação aos homossexuais teria que ser expressa. Como se sabe, nenhum constituinte chegou ao ponto de sugerir a inclusão da explícita da permissão para discriminação aos homossexuais no texto constitucional, de modo que prevalece, nessa seara, o princípio geral da não discriminação, que tem aplicação direta e imediata, ou seja, não depende de lei para ser aplicado. Portanto, mesmo aqueles deputados que aprovaram a redação do artigo $226, \S 3^{\circ}$, da $\mathrm{CF} / 88$, não tinham necessariamente a intenção de dizer que os casais homossexuais poderiam ser discriminados negativamente e qualquer afirmação em contrário é mera especulação.

Aliás, já que estamos no campo das especulações, imagino que seria bastante difícil que a maioria dos constituintes tivesse em mente, ao aprovar o referido parágrafo, que fosse possível conceder um benefício fiscal a casal heterossexual e negar o mesmo benefício a um casal homossexual, apenas em razão dessa opção sexual. Também acho bastante improvável imaginar alguém com uma mentalidade tão maldosa ao ponto de não permitir, deliberadamente, a concessão de licença para tratamento de saúde do companheiro apenas porque o companheiro é do mesmo sexo. Do mesmo modo, dificilmente alguém poderia pensar que as regras sucessórias relativas a um casal homossexual seguissem uma lógica diferente daquelas regras aplicáveis a um casal heterossexual. Nada disso foi debatido claramente durante a assembléia constituinte, de modo que não se poder concluir qual seria a vontade dos constituintes a respeito disso.

Se fosse possível perguntar, hoje, a cada um dos deputados que participaram da votação do texto constitucional o que eles pensam sobre cada um desses assuntos, seria muito complicado, do ponto de vista lógico, que eles negas- 
sem os direitos dos homossexuais sem caírem em contradição. Não há dúvida de que alguns deputados acreditavam que a inclusão da expressão "entre o homem e a mulher" iria impedir o reconhecimento das uniões estáveis homoafetivas, pois foi exatamente isso que eles disseram. Mas muitos outros deputados podem ter entendido que a união homoafetiva não estava em debate e aprovaram o texto apenas para garantir a equiparação da união estável ao casamento. E certamente foi esta a principal intenção dos constituintes ao aprovarem o referido artigo 226, $\S 3^{\circ}$, da CF/88: acabar com a velha ideia de que apenas as relações matrimoniais merecem plena proteção jurídica do Estado. Mesmos as uniões afetivas "sem papel passado" podem gozar as mesmas vantagens concedidas aos casais "de papel passado". É isso e nada mais do que isso que se pode extrair, com toda certeza, da leitura do referido artigo. Os discursos disponíveis hoje são completamente insuficientes para se ter uma certeza sobre o que, de fato, se passou na cabeça de todos os parlamentares acerca das uniões homoafetivas.

\section{(i. A interpretação do Supremo Tribunal Federal é tão ABSURDA ASSIM?}

Mesmo sendo capaz de reconhecer a razoabilidade da interpretação constitucional apresentada pelos críticos, no sentido de que não foi a intenção dos constituintes reconhecer a validade jurídica das uniões estáveis homoafetivas, entendo que essa não é a única interpretação possível, muito menos a melhor. O texto constitucional, a meu ver, é ambíguo e deixa a questão das uniões estáveis homoafetivas em aberto, dando ao Judiciário a possibilidade de decidir a questão com base em outros preceitos constitucionais.

Podem ser identificadas pelo menos quatro interpretações possíveis do tratamento constitucional das relações homoafetivas.

Pela primeira, os constituintes desejavam proibir a equiparação das uniões homoafetivas às demais formas de entidade familiar e, consequentemente, o legislador poderia negar aos casais homossexuais os mesmos direitos concedidos aos casais heterossexuais. Esta é a interpretação dos críticos à decisão do Supremo Tribunal Federal, que tem como ponto forte a seu favor a manifestação de vontade expressa de alguns membros da assembleia constituinte com feição mais conservadora que tiveram a intenção, ao incluírem no texto constitucional, a expressão "entre o homem e a mulher", evitar qualquer extensão dos direitos familiares aos homossexuais. Por outro lado, como ponto negativo, essa interpretação acarreta uma capitis deminutio aos homossexuais, colocando-os como sujeitos de segunda categoria, o que parece ser incompatível com o restante do texto constitucional.

Pela segunda interpretação, a Constituição teria proibido o reconhecimento da união estável entre pessoas do mesmo sexo, mas, como não foi 
incluída a expressão "entre o homem e a mulher" na definição de casamento, os homossexuais poderiam se casar entre si, por falta de norma proibitiva expressa. Essa interpretação seria uma forma de provocar os adeptos da primeira interpretação quando se apegam ferrenhamente à expressão "entre o homem e a mulher" para negar o direito dos homossexuais. Se tal expressão é tão importante e faz tanta diferença para impedir o reconhecimento das uniões estáveis homoafetivas, então ela também deveria estar presente para impedir o casamento gay. Como, no texto constitucional, não há nada que diga que o casamento é exclusivamente "entre o homem e a mulher", estaria aberta a possibilidade para o casamento entre pessoas do mesmo sexo, já que é inconstitucional qualquer regulação infraconstitucional que discrimine as pessoas em razão do sexo ou orientação sexual. Tal interpretação, ainda que possa desmascarar o apego à letra da Constituição que tem sido o principal trunfo utilizado para negar o direito dos homossexuais, certamente gera uma incongruência lógica no tratamento da matéria e, por isso, não parece ser a melhor interpretação. A aceitação do casamento entre pessoas do mesmo sexo pressupõe uma mudança cultural em torno da própria relação homoafetiva e, portanto, não parece ser coerente proibir o menos (união estável) e permitir o mais (casamento).

A terceira interpretação possível tenta conciliar uma leitura estrita do artigo $226, \S 3^{\circ}$, da $\mathrm{CF} / 88$, com o artigo $3^{\circ}$, inc. IV, que proíbe a discriminação por quaisquer motivos. Dentro dessa lógica, as uniões estáveis homoafetivas não poderiam ser consideradas como entidade familiar, mas os direitos que fossem concedidos aos casais heterossexuais não poderiam ser negados, sem razão plausível, aos casais homossexuais. Assim, independentemente de os homossexuais poderem ou não constituir família juridicamente válida, qualquer tratamento diferenciado entre um casal homossexual e um casal heterossexual deveria ser justificado para ser legítimo. Se a lei permite que uma pessoa heterossexual faça a dedução das despesas de saúde ou de instrução do companheiro heterossexual na declaração de imposto de renda, o mesmo direito deveria ser garantido às pessoas homossexuais, sob pena de incompatibilidade com o princípio de proibição de discriminação. Se a lei autoriza que um servidor público heterossexual possa pedir licença para tratamento de saúde do companheiro heterossexual, o mesmo direito deve ser estendido aos servidores públicos homossexuais em respeito à isonomia. Essa interpretação, certamente, "salva as aparências" e pode ser considerada como melhor do que as duas acima. Porém, ainda assim, continua rebaixando os homossexuais, na medida em que não reconhece a sua relação como uma relação familiar, e tem pouca ou nenhuma utilidade prática em relação à próxima interpretação, que, a meu ver, é a melhor.

Finalmente, a quarta forma possível de interpretar a Constituição seria reconhecer que o rol de entidades familiares que merecem proteção jurídi- 
ca adotado pelos constituintes foi meramente exemplificativo. Aquelas formas familiares expressamente contempladas no texto constitucional, como as uniões estáveis heteroafetivas, representaram um avanço em relação à mentalidade da época, mas não são capazes de impedir que outras formas de entidade familiar sejam reconhecidas com a evolução da sociedade. Essa foi a interpretação dada pelo Supremo Tribunal Federal e tem o mérito principal de, a um só tempo, elevar o status de dignidade de um grupo historicamente oprimido e abrir o conceito de entidade familiar para que a ordem jurídica possa captar as mudanças culturais nessa seara tão dinâmica.

Essa última interpretação é perfeitamente conciliável com a literalidade do artigo $226, \S 3^{\circ}$, da $\mathrm{CF} / 88$, que representou um avanço em relação ao tratamento da matéria, na medida em que reconheceu expressamente a união estável entre o homem e a mulher, facilitando a conversão de sua situação em casamento.

Uma leitura rápida do artigo $226, \S 3^{\circ}$, da $\mathrm{CF} / 88$ poderia induzir o leitor a pensar que as relações entre pessoas do mesmo sexo não foram protegidas pelos constituintes e, portanto, podem ser proibidas. Contudo, basta analisar atentamente o referido dispositivo para perceber que a norma constitucional, considerada em si mesma, não proíbe as relações entre pessoas do mesmo sexo, nem mesmo autoriza a discriminação negativa em relação a essas pessoas. A norma apenas prevê uma discriminação positiva para o casal formado por homem e mulher. Ou seja, o Estado tem a obrigação de reconhecer a união estável heterossexual e estimular que esses relacionamentos sejam convertidos em casamento. Obviamente, o mesmo reconhecimento não foi expressamente dado a uniões homoafetivas. Mas o fato de a Constituição não haver contemplado em seu texto as uniões entre pessoas do mesmo sexo não significa dizer que ele pode discriminar negativamente os homossexuais.

A Constituição consagra o direito de cada pessoa de ser tratada com igualdade em relação à sua identidade cultural e sexual, ainda quando esta se distancie dos padrões hegemônicos da sociedade envolvente (direito à diferença). Por isso, em princípio, seria inválida qualquer medida tendente a desrespeitar as diferenças, sem qualquer critério plausível. Na verdade, a ideia mais elementar de igualdade jurídica é precisamente esta: os benefícios normativos conferidos a uma pessoa não podem ser arbitrariamente negados a outros seres humanos sem um motivo legítimo.

Certamente, os constituintes brasileiros poderiam, se assim quisessem, estabelecer restrições aos homossexuais, sem que, hoje, se pudesse alegar a inconstitucionalidade da vontade constitucional originária. Porém, não há nada na $\mathrm{CF} / 88$ que autorize a conclusão de que seja possível limitar direitos por questões de opção sexual ou que os casais de pessoas do mesmo sexo podem sofrer restrições jurídicas decorrentes da sua condição. 
Para reforçar esse entendimento, podem ser comparados os seguintes artigos constitucionais:

Art. $5^{\circ}$ - XXXVIII - é reconhecida a instituição do júri, com a organização que lhe der a lei, assegurados (...)".

Art. 226, § $3^{\circ}$ - Para efeito da proteção do Estado, é reconhecida a união estável entre o homem e a mulher como entidade familiar, devendo a lei facilitar sua conversão em casamento".

Art. 231. São reconhecidos aos índios sua organização social, costumes, línguas, crenças e tradições, e os direitos originários sobre as terras que tradicionalmente ocupam, competindo à União demarcá-las, proteger e fazer respeitar todos os seus bens.

Essas três passagens da Constituição Federal de 1988 têm uma estrutura linguística muito parecida. Todas obrigam o Estado a reconhecer algo.

No primeiro caso, o fato de o Estado ser obrigado a reconhecer o júri não significa dizer que outras instituições semelhantes de solução de litígios não possam ser reconhecidas. A arbitragem, por exemplo, é uma instituição cujo "reconhecimento" não está na Constituição, mas ninguém duvida que é possível estabelecer alguns julgamentos por essa técnica, conforme já aceitou o próprio Supremo Tribunal Federal ${ }^{21}$.

$\mathrm{O}$ fato de o Estado ser obrigado a reconhecer a cultura indígena não significa dizer que outras formas culturais não podem ser reconhecidas, desde que lícitas. A Opus Dei, por exemplo, é uma organização religiosa que merece o reconhecimento do Estado, ainda que sua existência não esteja prevista na Constituição, nem na lei.

Então, o que leva a crer que o artigo $226, \S 3^{\circ}$, da $\mathrm{CF} / 88$, impede o reconhecimento de outras formas de união estável? A meu ver, apenas o desejo de negar aos homossexuais o direito de serem tratados como família.

\section{CRÍtica aos CRíticos}

Streck, Oliveira e Barreto, ao justificarem suas críticas ao reconhecimento das uniões homoafetivas pela via judicial, argumentaram que a opção de excluir os homossexuais de qualquer tipo de proteção familiar foi do próprio poder constituinte originário. Logo, como uma norma constitucional não pode ser, ao mesmo tempo, inconstitucional, a extensão de qualquer direito aos homossexuais que não passe pelo crivo do parlamento seria uma vitória "no tapetão" (expressão minha), “como se fosse possível fazer um 'terceiro turno' no processo constituinte" (expressão deles). Para eles, permitir que o Judiciário se substitua ao

${ }_{21}$ STF, SE 5206 AgR, rel. Min. Sepúlveda Pertence, j. 12/12/2001. 
legislador para colmatar lacunas do próprio poder constituinte seria incentivar a criação de uma "Constituição paralela" (uma verdadeira "Constituição B"), "estabelecendo, a partir da subjetividade dos juízes, aquilo que 'indevidamente' - a critério do intérprete - não constou do pacto constituinte" (STRECK, OLIVEIRA \& BARRETO, 2011).

Para reforçar seus argumentos, os referidos autores citam dois exemplos que, na ótica deles, guardam semelhança com a situação das uniões homoafetivas: a não previsão constitucional de legitimidade ativa para que os municípios proponham ação direta de inconstitucionalidade e o tratamento diferenciado entre homem e mulher para fins de aposentadoria. Segundo eles, seria absurdo permitir que, sob o fundamento de isonomia, o Judiciário "corrigisse" o texto constitucional para equiparar os critérios de aposentadoria ou para estender o direito de propor ADIn aos municípios.

O exemplo do tratamento diferenciado entre homem e mulher, a meu ver, reforça a tese de que a Constituição não autorizou a discriminação aos homossexuais. Vejamos.

A Constituição contempla, sem dúvida, tanto uma proibição de discriminação de gênero (sexo) quanto de opção sexual. Mesmo sendo proibida a discriminação entre homem e mulher, o constituinte fez uma opção expressa de criar regras distintas de aposentadoria conforme o gênero: as mulheres aposentam-se com menos tempo de contribuição e menos idade do que os homens. Isso demonstra que os constituintes, se quiserem, podem discriminar explicitamente, sem que sejam acusados de praticar inconstitucionalidade. Porém, no que se refere à discriminação entre homem e mulher na questão da aposentadoria os constituintes foram claros: as mulheres terão o tratamento " $\mathrm{X}$ " e os homens terão o tratamento "Y".

No caso das uniões estáveis, o constituinte disse apenas que as uniões estáveis entre o homem e a mulher terão o tratamento "Z", mas silenciou em relação ao tratamento que seria dado às uniões estáveis homoafetivas. Os constituintes deveriam, se quisessem discriminar, ter dito: "as uniões estáveis entre homem e mulher terão o tratamento ' $Z$ ', e as uniões homoafetivas não terão o mesmo tratamento". Ou então poderiam ter dito o seguinte: "apenas as uniões entre o homem e mulher terão o tratamento ' $Z$ '", ou ainda, "o tratamento 'Z' será dado exclusivamente às uniões estáveis entre homem e mulher'. Como nada disso foi dito, prevalece o princípio geral de não discriminação, ou seja, o tratamento não pode ser diferenciado, pois qualquer tipo de discriminação teria que ser expressa.

Essa discriminação expressa também está prevista, por exemplo, quando os constituintes determinaram que são privativos de brasileiros natos os 
cargos previstos no artigo $12, \S 3^{\circ}$, da $\mathrm{CF} / 88$, apesar do princípio de igualdade entre brasileiros natos e naturalizados (art. 12, $\S 2^{\circ}$, da CF/88). Quando o princípio geral é a não discriminação, qualquer discriminação tem que ser autorizada de forma expressa por meio de palavras de exclusão (privativamente, exclusivamente, apenas, unicamente, somente, exceto etc.). Ausentes tais palavras, há de prevalecer a igualdade.

O exemplo da legitimidade ativa dos municípios para a propositura de ADIn exige conhecimentos mais sofisticados, pois envolve uma compreensão do princípio federativo e da exigência da simetria a ele correlato. Simplificando a questão, pode-se dizer que o princípio federativo não obriga um tratamento absolutamente idêntico entre municípios e estados, bastando lembrar que os municípios não possuem Poder Judiciário, nem Constituição, mas apenas uma lei orgânica. Isso faz com que seja inadequado usar o princípio da igualdade (ou da simetria) para estender aos municípios prerrogativas dadas aos estados. Daí porque não caberia estender aos municípios a prerrogativa de propor ADIn, cujo rol de legitimados é taxativo, segundo entendimento do $\mathrm{STF}^{22}$. Mas, quando há um dever de tratamento igualitário (ou de simetria), esse tipo de extensão parece ser possível. Basta ver, por exemplo, que os estados, por força da simetria com a União, podem criar CPIs, com poderes de autoridade judiciária ${ }^{23}$, bem como podem usar o instituto da medida provisória com força de lei ${ }^{24}$, embora não exista previsão expressa a esse respeito na Constituição Federal de 1988.

Em resumo, o que importa verificar é se há um dever de igualdade: se há o dever de igualdade e não há norma expressa prevendo a discriminação, o tratamento diferenciado presume-se ilegítimo.

Seria possível avançar várias outras críticas aos referidos autores, especialmente pelo fato de eles distorcerem quase por completo a filosofia de Ronald Dworkin, usando o peso de seu nome para combater exatamente aquilo que o jurista norte-americano mais defende: a jurisdição constitucional em favor da realização do princípio da igual consideração e respeito. Mas avançar nesse terreno seria desviar o foco da discussão, pois teríamos que fugir do debate concreto sobre as uniões homoafetivas para entrar no campo árido da interpretação teórica, o que não é a minha proposta neste texto.

\section{O Texto e o Contexto}

Não se pode negar que essa perspectiva pró-homoafetividade foi estimulada por uma mudança de contexto ocorrido a partir da própria sociedade

\footnotetext{
${ }_{22}$ STF, Rcl 397 MC-QO, rel. Min. CELSO DE MELLO, j 25/11/1992.

${ }^{23}$ STF, ADI 3619, rel. min. EROS GRAU, j. 01/08/2006.

${ }^{24}$ STF, ADI 425, rel: Min. MAURÍCIO CORRÊA, j. 04/09/2002.
} 
brasileira, que se tornou mais tolerante em relação aos homossexuais. É provável que nem mesmo os deputados mais progressistas imaginassem que a sociedade fosse avançar tanto a ponto de tratar os homossexuais como sujeitos de direito merecedores de respeito e consideração. Nos anos 1980, época em que foi promulgada a Constituição, ninguém poderia sonhar que, vinte anos depois, milhões de pessoas ocupariam as ruas da Avenida Paulista em defesa do "orgulho gay" e que diversos países ocidentais passassem a reconhecer juridicamente a família homoafetiva.

A teoria contemporânea da interpretação tem defendido que um mesmo enunciado pode ter vários significados, conforme o contexto vivenciado pelos intérpretes da mensagem. Hoje, tornou-se truísmo reconhecer que a norma não se esgota no texto legal, já que a letra da lei é apenas o ponto de partida da realização do Direito. Friedrich Müller, por exemplo, sugeriu que o texto normativo seria apenas o "programa da norma", ou "a ponta do iceberg" do fenômeno jurídico. Não seria o teor literal da norma que regulamentaria o caso jurídico, mas uma série de fatores extratextuais relacionados ao contexto da interpretação (MÜLLER, 2000).

O contexto da interpretação importa e muito. Não se pode interpretar um texto normativo sem levar em conta a realidade em que ele está inserido, pois os sentidos das palavras variam conforme o contexto e só podem ser identificados no contexto. O melhor sentido de uma mensagem somente pode ser obtido através de uma série de operações de decifração que começa com cada fonema isolado, passa pela formação das palavras, depois da frase até chegar ao contexto e vice-versa. Como disse Koestler, "as frases estão relacionadas com o contexto, da mesma maneira como as palavras com a frase, e os fonemas com as palavras" (KOESTLER, 1969, p. 51). Daí porque é impossível pensar-se em um enunciado independentemente do contexto ou então em um sentido único e definitivo para uma frase que não esteja vinculada às experiências de vida partilhadas pela respectiva "comunidade interpretativa" a quem ela é dirigida ${ }^{25}$. No caso dos direitos dos homossexuais, há uma imensa mudança de contexto e uma profunda transformação da bagagem cultural compartilhada pela "comunidade interpretativa".

Essa mudança de interpretação de uma prática jurídica a partir da mudança do contexto social é muito comum no direito de família. O conceito de entidade familiar tem se alterado ao longo do tempo e nem sempre o legislador tem sido rápido o suficiente para acompanhar as mudanças da sociedade. Com frequência, os julgadores, na solução de problemas jurídicos relacionados à família, tentam captar os anseios sociais e buscam uma sintonia com os costumes aceitos como válidos pela sociedade, antecipando-se às modificações legislativas. Foi assim com o reconhecimento da validade jurídica da separação de fato, antes

${ }_{25}$ Basta invocar, para esse fim, ainda que com alguma cautela, a lição de Stanley Fish, sobretudo aquela exposta em "Is There a Text in This Class?” (FISH, 1980, pp. 303/321). 
mesmo de ter sido aprovada a lei do divórcio; com o reconhecimento da validade jurídica do concubinato, antes mesmo de haver uma lei regulamentando a união estável; com o reconhecimento jurídico da chamada guarda compartilhada, antes de haver uma regulamentação sobre o assunto. E também ocorreu o mesmo com o reconhecimento jurídico das uniões homoafetivas, mesmo não existindo uma lei expressa sobre o tema. Em todas essas situações, os costumes, ou melhor, as transformações sociais foram o fator preponderante para a solução do caso e para a gradual consolidação da jurisprudência, seguida da mudança legislativa. Em todas essas situações, o percurso seguido pela evolução do direito foi este: costumes $\rightarrow$ jurisprudência $\rightarrow$ legislação. A questão das uniões homoafetivas insere-se perfeitamente nessa lógica.

Desejo fazer uma última observação que, a meu ver, é de extrema importância, já que envolve uma mudança de postura diante da solução de casos jurídicos. Entendo que a pergunta fundamental na interpretação de um texto jurídico não é saber qual é o significado das palavras que ali estão escritas, mas sim tentar descobrir qual é o problema que a norma se propõe a resolver. Não se deve perguntar se a palavra " $X$ " escrita na lei "Y" tem o significado "A" ou "B". Deve-se perguntar qual o propósito daquele enunciado, ou seja, qual era a situação problemática que existia e que tipo de solução pretendeu-se fornecer com a aprovação daquele texto. Em outras palavras, a atividade "hermenêutica" do jurista não se restringe a descobrir quais são as intenções semânticas "do texto", mas sim buscar o seu sentido normativo. Buscar a intenção normativa do texto não significa convocar uma imaginária "vontade do legislador" nem mesmo uma fictícia "vontade constitucional", mas sim verificar que respostas normativas (diante dos problemas ocorridos no passado) a norma se propôs a fornecer e saber se essas respostas são adequadas aos problemas concretos que se está enfrentando no presente.

No caso do artigo $226, \S 3^{\circ}$, da $\mathrm{CF} / 88$, o problema que os constituintes desejavam resolver era o problema da união estável heteroafetiva e a sua consequente equiparação ao casamento. A aprovação do referido dispositivo constitucional teve o claro intuito de garantir às referidas uniões o mesmo tipo de proteção jurídica conferida ao casamento. A inclusão da expressão "entre o homem e a mulher" foi uma forma de evitar o debate acerca das uniões homoafetivas, que, a rigor, não constituía um genuíno problema aos parlamentares da época. Portanto, o problema das uniões homoafetivas, rigorosamente, não foi tratado pela assembleia constituinte, a não ser de forma transversa, o que abre a possibilidade para uma interpretação mais aberta do estatuto constitucional das uniões homoafetivas.

E, mesmo que esse tema tivesse sido enfrentado de forma específica, ainda assim não podemos perder de vista que o contexto da discussão era 
completamente diferente do contexto atual e, portanto, não seria tão absurda assim uma atualização do texto pela via interpretativa (mutação constitucional), o que, a meu ver, não foi o caso, pois sequer foi necessário chegar a tanto, uma vez que o texto constitucional nunca havia sido interpretado, pelo STF, de forma diferente daquela interpretação dada na ADPF 132/RJ.

\section{Conclusão}

Os argumentos a favor da decisão do Supremo Tribunal Federal desenvolvidos ao longo deste trabalho seguiram uma linha de raciocínio tradicional na hermenêutica jurídica, que adota como pressuposto a ideia de que a solução dos problemas jurídicos depende de uma interpretação semântica de textos normativos previamente aprovados por instâncias autorizadas a tanto.

Particularmente, penso que existem outros métodos mais condizentes com a atual fase de evolução do pensamento jurídico, especialmente em razão do avanço da jurisdição constitucional dos direitos fundamentais e com o alargamento da razão jurídica, proporcionado pela pluralização e multiplicação das fontes do Direito. Acredito, por exemplo, que o raciocínio do julgador deve ser guiado por motivos diferentes daqueles que regem o processo legislativo, pois os argumentos de princípio devem ter um peso maior do que os argumentos de política. Também defendo que os direitos fundamentais devem funcionar como trunfos em favor das minorias em desvantagem, tal como sugerido por Ronald Dworkin, de modo que a vontade do legislador, por mais majoritária que seja, nem sempre merece prevalecer (DWORKIN, 1984, pp. 153/167). Além disso, acredito que a forma de interpretar um texto jurídico não consiste em buscar a intenção dos seus autores, mas sim em indagar que tipo de problema a norma pretende solucionar e se a controvérsia a ser solucionada enquadra-se nos propósitos da norma (NEVES, 1993, 2003 e 2008; SCHAPP, 1985). Isso sem falar que, na minha ótica, e mais uma vez inspirando-me em Dworkin, acredito que os juízes devem realizar uma "leitura moral" (moral reading) da Constituição como forma de extrair do texto constitucional o espírito ético que dele brota (DWORKIN, 2006).

Porém, minha pretensão ao escrever este texto não foi defender nenhum método jurídico específico, nem mesmo sugerir que os críticos da decisão do Supremo Tribunal Federal estão adotando uma forma de raciocínio ultrapassada. O que tentei demonstrar foi que, mesmo adotando os pressupostos clássicos da teoria hermenêutica, não se pode dizer que o Supremo Tribunal Federal violou os limites semânticos da Constituição ou usurpou a autoridade do Congresso Nacional. A solução adotada pelo Supremo Tribunal Federal, no caso das uniões estáveis homoafetivas, é perfeitamente compatível com a literalidade do texto constitucional e, o que é mais importante, espelha uma filosofia moral plenamente 
afinada com a ideia de expansão do círculo ético ${ }^{26}$, que, a meu ver, é o principal parâmetro de legitimidade de qualquer decisão.

O texto final da Constituição, no tema das uniões estáveis, resultou de um arranjo de compromisso entre diversos setores antagônicos, o que significa dizer que não resultou em nada muito preciso. Se alguém disser taxativamente que os constituintes pretenderam permitir a discriminação negativa aos homossexuais, certamente está especulando, pois, pela simples análise do texto, não é possível saber.

Existem, como tentei demonstrar, pelo menos quatro interpretações possíveis envolvendo o estatuto constitucional das uniões homoafetivas. Poder-se-ia interpretar o texto constitucional no sentido de excluir as relações homossexuais de qualquer definição de entidade familiar, negando às uniões homoafetivas os direitos próprios das relações heterossexuais. Poder-se-ia entender que a Constituição impediu expressamente a união estável homoafetiva ao incluir a expressão "entre o homem e a mulher" no texto constitucional, mas, ao não incluir a mesma expressão no conceito de casamento, abriu a possibilidade para o reconhecimento da união matrimonial entre pessoas do mesmo sexo. Poder-se-ia também entender que, mesmo não sendo entidade familiar, não poderia haver discriminação negativa em relação aos casais homossexuais, de modo que eles gozariam dos mesmos direitos garantidos aos casais heterossexuais. Finalmente, poder-se-ia extrair da Constituição um mandamento de não discriminação às relações homoafetivas e uma abertura na definição de entidade de familiar, a fim de que os tribunais possam atualizar o texto à medida da evolução da sociedade.

Quando há tantas opções de interpretação e nenhuma delas pode ser categoricamente considerada como a única solução possível, a melhor alternativa é escolher a interpretação com base em razões éticas que, no presente caso, encontram-se positivadas no princípio de não-discriminação. Se ninguém pode discriminar ninguém por motivo de opção sexual, é ilegítimo negar qualquer benefício a uma pessoa apenas pelo fato de ele se assumir como homossexual. E se a interpretação dos críticos for considerada a única possível, os casais homoafetivos terão seus direitos negados apenas porque não são heterossexuais, o que não parece ser compatível com a integridade do texto constitucional. A lógica é muito simples: heterossexuais e homossexuais devem ser tratados de forma igual. Os heterossexuais recebem o tratamento F; logo, os homossexuais também devem receber o mesmo tratamento.

${ }^{26}$ A ideia da expansão do círculo ético foi desenvolvida por Lecky, no seu "A History of European Morals", de 1869: "At one time, the benevolent affections embrace merely the family, soon the circle expanding includes first a class, then a nation, then a coalition of nations, then all humanity and finally, its influence is felt in the dealings of man with the animal world. In each of these stages a standard is formed, different from that of the preceding stage, but in each case the same tendency is recognised as virtue" (LECKY, 1917, p. 100/101). Recentemente, o filósofo Peter Singer retomou a mesma ideia para defender com mais ênfase a inclusão dos animais não-humanos no círculo ético (SINGER, 1981 e 2005). 
Admitindo-se que as quatro interpretações anteriores são possíveis, somente um capricho arbitrário, talvez motivado por valorações religiosas ou mesmo preconceitos culturais, justificaria dizer que a interpretação que exclui os homossexuais do círculo de proteção constitucional é a melhor. Os que são simpáticos à causa dos homossexuais e, ao mesmo tempo, críticos da decisão do STF não podem se esquivar da discussão com a cômoda alegação de que a culpa é da assembleia constituinte, porque essa não é a única interpretação possível da Constituição. A questão, portanto, deve ser resolvida a partir de um debate transparente e sincero em torno dos direitos dos homossexuais: podem os homossexuais ser tratados como sujeitos de segunda categoria? Podem ser concedidas inúmeras vantagens a duas pessoas que vivem em relação afetiva, mas negar essas mesmas vantagens a outras duas pessoas apenas porque ambas são do mesmo sexo? Quem tiver coragem e argumentos para justificar a discriminação que o faça abertamente, sem escudos hermenêuticos que mascaram o debate de fundo.

De minha parte, entendo que qualquer decisão que contribua para a expansão do círculo ético, permitindo a construção de uma comunidade moral mais inclusiva, tende a ser legítima. Por outro lado, quando a jurisdição impede a expansão do círculo ético ou reduz o círculo ético ela certamente é ilegítima, por mais que receba o aplauso da maioria da população e até mesmo da "consciência jurídica geral".

No caso da ADPF 132/RJ, a solução do Supremo Tribunal Federal foi no sentido de incluir uma categoria de pessoas que até então não estava inserida no contexto das preocupações morais de muitos membros da sociedade brasileira. Por isso, ela merece todos os aplausos de qualquer ser humano que se preocupa com o próximo e atende com perfeição ao mandamento constitucional de construção de uma sociedade justa e solidária, sem preconceito de qualquer natureza. 


\section{REFERÊNCIAS}

ACKERMAN, Bruce. The Rise of World Constitutionalism (1996). Occasional Papers. Paper 4. Disponível em: <http://tinyurl.com/422ugo8> Acesso em $21 / 5 / 2010$

ARRUDA, Antônio Francisco Mota Ferraz de. União homossexual afetiva, o STF e a construção do direito. In: Blog do Fred. Disponível em: $<$ http://tinyurl. com/42vw9dr> Acesso em 25/5/2011

BICKEL, Alexander. The Least Dangerous Branch: the Supreme Court at de bar of politics. Indianapolis: Bobbs-Merrill, 1962

BISOL, Paulo. Discurso na Comissão de Soberania e dos Direitos e Garantias do Homem e da Mulher (Assembleia Constituinte - Atas de Comissões). Senado Federal: Brasília, 1987

CANOTILHO, J. J. Gomes. Direito Constitucional e Teoria da Constituição. $5^{\text {a }}$ edição. Coimbra: Portugal, 1997 ( $\left.1^{\text {a }} \mathrm{Ed}\right)$

DOUGLAS, William. STF Quis Reescrever Constituição. In: Portal Conjur. Disponível em: < http://tinyurl.com/3pgg6h3> Acesso em 24/5/2011

DWORKIN, Ronald. Uma Questão de Princípio (A Matter of Principle). São Paulo: Martins Fontes, 2001

DWORKIN, Ronald. Justice in Robes. New York: Harvard University Press, 2006 DWORKIN, Ronald. Direito da Liberdade: leitura moral da Constituição norte-americana (Freedom's law: the moral reading of the. American Constitution). São Paulo: Martins Fontes, 2006

DWORKIN, Ronald. Rights as Trumphs. In: WALDRON, Jeremy (org.). Theories of Rights. Oxford: Oxford University Press, 1984

ELY, John Hart. Democracy and Distrust: a theory of judicial review. Cambridge: Harvard University Press, 2002

FERREIRA, Costa. Discurso na Comissão de Soberania e dos Direitos e Garantias do Homem e da Mulher (Assembléia Constituinte - Atas de Comissões). Senado Federal: Brasília, 1987

FISH, Stanley. Is There a Text in This Class? The Authority of Interpretive Communities. Cambridge: Harvard University Press, 1980

HABERMAS, Jürgen. Direito e Democracia entre facticidade e validade (Faktizität und Geltung. Beiträge zur Diskursstheorie des Rechits und des demokratische Rechitstaats, 1992). v. I. Trad: Flávio Beno Siebeneichler. Rio de Janeiro: Tempo Brasileiro, 1997

HISRCHL, Ran. Towards Juristocracy: the origins and consequences of the new constitutionalism. Cambridge: Harvard University Press, 2004, p. 1 
IRONS, Peter. A People's History of the Supreme Court: The Men and Women Whose Cases and Decisions Have Shaped Our Constitution. New York: Viking, 1999

JESUS, Atônio. Discurso na Comissão de Soberania e dos Direitos e Garantias do Homem e da Mulher (Assembleia Constituinte - Atas de Comissões). Senado Federal: Brasília, 1987

KOESTLER, Arthur. O Fantasma na Máquina (The Ghost in the Machine). Rio de Janeiro: Zahar Editores, 1969

LARENZ, Karl. Metodología de La Ciencia del Derecho. Madrid: Ariel Derecho, 1994

LECKY, W. E. Hartpole. History of European morals - From Augustus to Charlemagne. v. 1, $3 \mathrm{a}$ ed., New York and London: D. Apleton and Company, 1917, p. $100 / 101$

MARMELSTEIN, George. Curso de Direitos Fundamentais. $3^{\text {a }}$ Ed. São Paulo: Atlas, 2011

MARTIN, Ives Gandra da Silva. Família é Aquela que Perpetua Sociedade. In: Portal Conjur. Disponível em: <http://tinyurl.com/4x8yh9v> Acesso em 24/5/2011 MENDES, Conrado Hubner. Direitos Fundamentais, Separação de Poderes e Deliberação. São Paulo: Tese de Doutorado (USP), 2008

MÜLLER, Friedrich. Métodos de Trabalho do Direito Constitucional. Trad. Peter Naumann. $2^{\text {a }}$ Ed. São Paulo: Max Limonad, 2000.

NEVES, A. Castanheira. Dworkin e a Interpretação Jurídica. In: Digesta: Escritos acerca do Direito, do Pensamento Jurídico, da sua Metodologia e Outros v. 3. Coimbra: Editora Coimbra, 2008

NEVES, A. Castanheira. O Actual Problema Metodológico da Interpretação Jurídica - I. Coimbra: Coimbra Editora, 2003

NEVES, A. Castanheira. Metodologia jurídica: problemas fundamentais. Coimbra: Coimbra, 1993.

SCHAPP, Jan. Problemas Fundamentais da Metodologia Jurídica. Porto Alegre: Sérgio Fabris Editor, 1985

SCHEPPELE, Kim Lane. Constitutional Interpretation after Regimes of Horror. In: Public Law and Legal Theory Research Paper Series n. 1-5, maio, 2000

SINGER, Peter. The Expanding Circle: Ethics and Sociobiology. Oxford: The Clarendon Press, 1981

SINGER, Peter. Como Haveremos de Viver? A Ética numa Época de Individualismo (How Are We To Live?, 1993). Trad: Fátima Aubyn. Lisboa: Dinalivro, 2005 
SILVA, Virgílio Afonso. A Constitucionalização do Direito. São Paulo: Malheiros, 2005,

SOUZA NETO, Cláudio Pereira de \& SARMENTO, Daniel. A Constitucionalização do Direito: fundamentos teóricos e aplicações específicas. Rio de Janeiro: Lumen Juris, 2007, pp. 89/111

SRECK, Lênio. Sobre a decisão do STF (Uniões Homoafetivas). In: Facebook. Disponível em <http://tinyurl.com/3rtg2qf> Acesso em 24/11/2010

STRECK, Lênio; OLIVEIRA, Rafael Tomas de; BARRETO, Vicente de Paulo. Ulisses e o canto das sereias: sobre ativismos judiciais e os perigos da instauração de um "terceiro turno da constituinte". In: Revista de Estudos Constitucionais, Hermenêutica e Teoria do Direito (RECHTD),1(2):75-83.

TUSHNET, Mark. Taking Constitution Away From the Courts. New Jersey: Princeton Unversity Press, 1999

VIEIRA, Oscar Vilhena. Supremocracia. Revista Direito GV, São Paulo 4(2), p. 441-464 jul-dez, 2008

WALDRON, Jeremy. The Core Case Against Judicial Review. The Yale Law Journal 115, 2006

\section{RAINBOW JUSTICE: COMMENTS ON THE BRAZILIAN SUPREME COURT DECISION REGARDING GAYS RIGHTS}

Abstrac: This study comments on the ruling of the Brazilian Supreme Court in ADPF 132/RJ, which recognized the legal validity of same-sex relationships. This decision caused great perplexity in some sectors of the Brazilian legal community and has provoked an important debate about the limits of constitutional jurisdiction in Brazil. For some, the Supreme Court would have extrapolated its constitutional function and made an illegitimate revision of the constitutional text. Examining the annals of constitutional debates, we sought here to demonstrate that the Supreme Court did not violate the semantic boundaries of the Constitution or usurped the authority of Congress. The solution adopted in ADPF 132/RJ is perfectly compatible with the literal meaning of the constitutional text and, more importantly, reflects a morality completely attuned to the idea of expanding circle of ethics, which can be considered the main measure of legitimacy.

Keywords: Contitutional interpretation. Judicial review. Judicial activismo. Gays rights.

Data de recebimento: nov/2010 - Data de aprovação: jan/2011 